\title{
Towards a Framework for Measuring Spatial Planning Outcomes in South Africa
}

\author{
Mac Mashiri $^{1}$, Peter Njenga ${ }^{2}$, Cecilia Njenga ${ }^{2}$, James Chakwizira $^{3, *}$, Maartin Friedrich $^{4}$ \\ ${ }^{1}$ Gwarajena TRD, 25A Barnstable Road, Lynnwood Manor 0081, PO Box 1683 Faerie Glen, South Africa \\ ${ }^{2}$ KENA Consult, 6 Gweru Street, Woodhill, Tshwane, South Africa \\ ${ }^{3}$ Department of Urban and Regional Planning, School of Environmental Sciences, University of Venda, South Africa \\ ${ }^{4}$ Manna Development Consultancy (Pty) Ltd, Pretoria, South Africa
}

Copyright $\bigcirc 2017$ by authors, all rights reserved. Authors agree that this article remains permanently open access under the terms of the Creative Commons Attribution License 4.0 International License

\begin{abstract}
This paper chronicles the process of developing a framework for measuring spatial planning outcomes in South Africa - defining and articulating the desired spatial planning outcomes as well as the mechanisms through which they can be measured. Given that the development of indicator sets and monitoring frameworks for spatial policy are considered as an ever-evolving iterative process as new agendas, challenges and opportunities emerge and others assume less importance, the paper proposes a suite of robust spatial development indicators which translate complex relationships involving a plurality of actors across different operationally independent policy sectors in a way that enables the tracking of spatial trends over time. It also enumerates the key success factors associated with implementing the proposed framework nestled on multiple spatial scales.
\end{abstract}

Keywords Spatial Planning Outcomes, Measurement Framework, Indicators, Spatial Justice, Key Success Factors, Capacity Building

\section{Introduction}

\subsection{Importance of Spatial Planning and the Complexity of Measuring its Outcomes}

Spatial planning is an important public policy instrument for establishing a long-term, sustainable framework for territorial and socio-economic development within a country. It can provide a vision and common direction for different sectoral policies as well as achieve synergies across different departments and spheres of government. Spatial planning can also help to promote investments, strengthen economic growth and inculcate social coherence while guiding policies for promoting more efficient use of resources and protecting the environment. Spatial planning thus provides a robust platform for entrenching sustainable and equitable socio-economic and environmentally sound development. On the other hand, evidence suggests that lack of or ineffective spatial planning often entails significant vulnerability to environmental degradation, natural disasters, inadequate basic services, strained municipal finances, and socio-political conflict over land and housing [1, 2, 3]. It also involves the prospect of being locked-in to fixed infrastructure networks that dictate inefficient patterns of land-use, carbon emissions, water and energy consumption, and wasteful use of other natural resources (ibid).

Current trends in spatial planning policies and practice are towards integrating land use with a variety of other sectoral policies and programs which influence the nature of places and how they function. Necessarily, measuring the results of spatial planning is a complex, multi-agency function that is heavily reliant upon the actions of a plurality of actors across different operationally independent policy sectors. Compounding this in South Africa is the dynamic and often complicated interaction between the horizontal axes of spatial planning that is intersected by the vertical complexity of activities across the different spheres of government [4]. This renders the goal of prescribing a single and straightforward method for measuring spatial planning outcomes illusory. The need therefore for a framework approach to the determination of desired spatial outcomes at various levels, and development of appropriate means to measure the outcomes cannot be over-emphasized. A framework typically provides a flexible and adaptable approach to managing and achieving the results of complex processes that involve disparate components.

The study profiled in this article therefore is in recognition of the perspective that the South African space economy, both at the macro and micro levels is characterised by an unequal and incoherent spatial structure that often stifles economic development and perpetuates the inherent inequalities wrought by the apartheid-based planning philosophy. Thus dismantling and transforming these spatial distortions and constructing new spatial forms, 
arrangements and relations that are conducive to the constitutional imperatives of nation building and socio-economic inclusion, is certainly a pressing preoccupation of development policy in the country.

\subsection{Rationale for the Development of an SPO Measurement Framework}

There are three fundamental reasons why municipalities and other spheres of government need a spatial planning performance management system, complete with appropriate indicators, namely:

- Determine spatial planning spending priorities: A results-based spatial planning outcomes budgeting approach connects resource allocation to specific, measurable results. Evidence of the impact and effectiveness of public investment can provide vital information to influence and amend strategic priorities. Prudent financial management demands municipalities to consider future operational costs and revenues of planned projects before approving them, budget processes and decisions should, at a minimum, be influenced by the impact of previous spending.

- Improve spatial planning outcomes and performance: This refers to the development and deployment of improved spatial planning policies, programs and processes to ensure adequate, quality and value-for-money services. Crafting suitable indicators can thus assist in targeting critical spatial planning tasks that effect developmental spatial change and achieve sustainable built and non-built environments, as well as in identifying what further changes and outcomes are desired, including measuring progress overtime. Where gaps exist in implementation, for example, (either through lack of skills, personnel or appropriate operational systems) capacity support interventions can then be implemented.

- Provide spatial planning outcomes accountability: Given that monitoring the detailed allocation and effects of public spending is a crucial feature of transparency in a democratic system, it is imperative to ensure public accountability between government and the citizenry, or internal accountability between spheres of government, or between department heads and elected politicians, or between senior managers and other officials.

\subsection{Research Objectives and Questions}

The overall aim of this paper is to present for South Africa a framework for measuring spatial planning outcomes complete with appropriate indicators. In order to realise this aim, three key objectives were derived as follows:

- Analyse different policies and various planning documents to determine the desired outcomes of spatial planning in South Africa

- Generate plan- and objective-derived spatial planning outcomes, and

- Develop a set of indicators that will be used to measure spatial planning outcomes across the country.

\section{Materials and Methods}

A mixed method approach underpinned by pragmatism was employed to collect the data to inform the development of a framework for measuring spatial planning outcomes [4, $5,6]$. Extensive literature reviews were undertaken to refine and consolidate the conceptual framework. Besides secondary data analysis, thematic discussions with selected municipal and provincial officials were also conducted thus using group interaction to generate basic data and rich insights. Stakeholder mobilization and engagement by way of tapping into the knowledge, experience and expertise of a wide cross-section of practitioners and other stakeholders was an integral component of the process flow for developing a robust framework.

A checklist of questions was employed to assist in structuring and directing the discussion rather than as a sacrosanct script to be read out and followed at all costs. Most of the questions were open-ended, giving the discussants the opportunity to pursue some issues in much greater detail and thus elicit a greater range and depth of information. In addition, key informants were requested to source, generate, and pass onto the research team other relevant information. In this regard, through the snowballing technique, informants initially targeted were requested to identify other key informants who, in their considered opinion, could provide useful information with which to sufficiently respond to the research questions - thus enabling contact with other informants not originally listed in the purposive (judgemental) sample as discussed above. Project implementation followed the process flow depicted in Figure 1. 


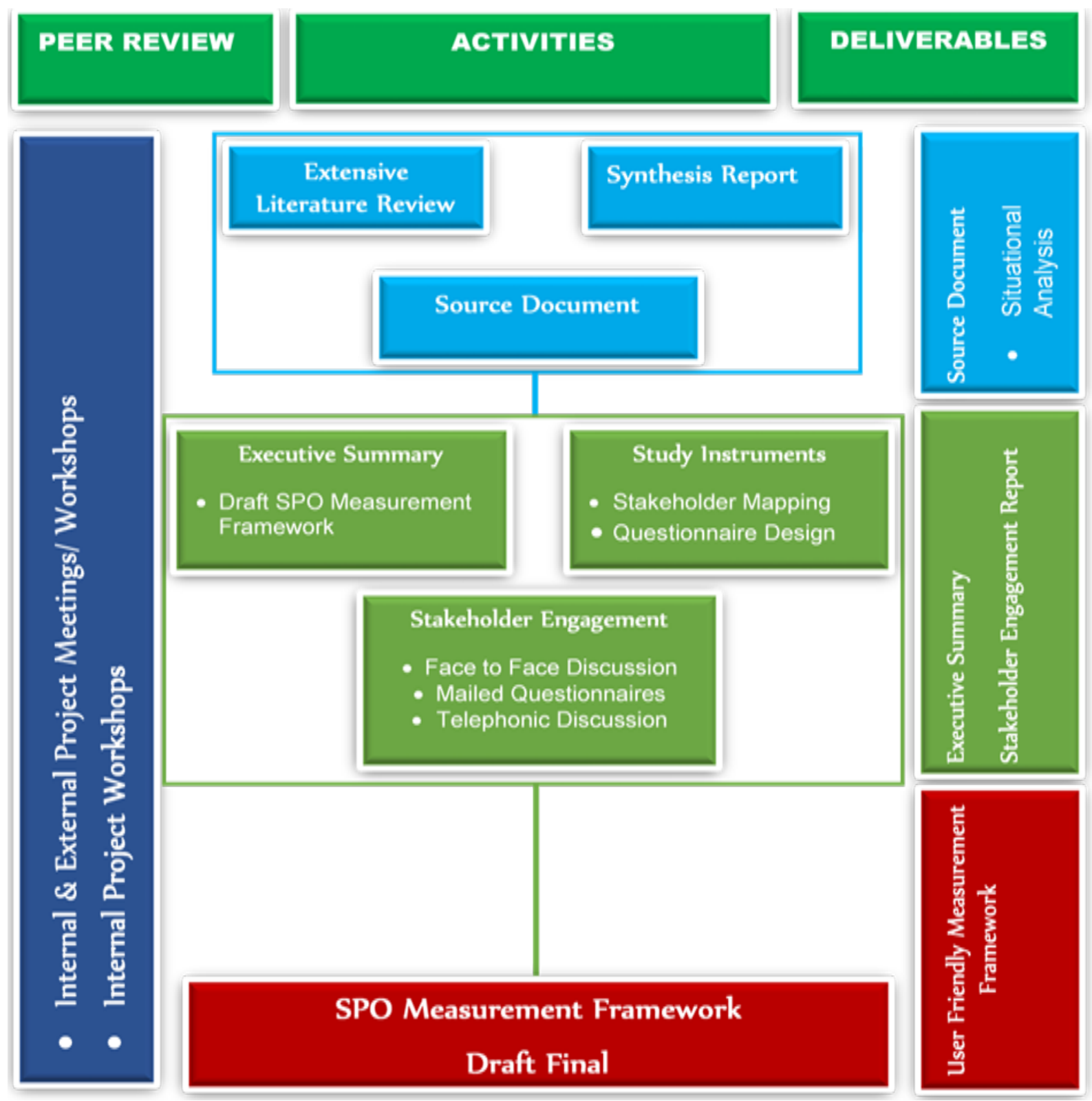

Figure 1. SPO Measurement Framework Process Flow

Data was analysed using mostly affinity charts - which essentially provide a systematic way of organising information and ideas into meaningful common themes with a view to unpacking the dominant threads to be used as input into the development of the measurement framework.

\section{Literature Review}

\subsection{Spatial Planning in Perspective}

The spatial planning system that exists in South Africa today has been shaped by the different incumbent governments, each responding to challenges deemed the most significant of the day. According to the White Paper on Spatial Planning [7], colonialism shaped the structure and form of human settlements in South Africa along racial and class lines, since 1652. The emerging patterns of human settlements laid the foundations for apartheid that emerged in the second half of the twentieth century. Apartheid was essentially an attempt at geographical partitioning of socio-economic and political opportunities which then led to the current distorted and disintegrative spatial structure. Oranje and Merrifield [8] distinguish four eras that mark spatial planning in South Africa, namely:

- The Ultra-Modernist period - which was the period 1930 to early 1940 ,

- The Grand Apartheid period - late 1960's to early 1980s, and

- Post-Apartheid period - 1990s to 2010 .

Each of the three periods was characterised by different sets of social, economic, ideological and political systems 
and coincided with periods where the South African economy and society were undergoing significant changes (ibid):

- $\quad$ 1930-1940 - saw the growth of urbanized workforce.

- 1960-1980 - saw the implementation of apartheid spatial implementation at micro and macro regional scales, which was followed by attempts at dealing with the failures and consequences of these policies at social, economic and political level.

- 1990-2010 - ushered the new democratic order.

The two authors argue that the spatial economic conditions that were being responded to had similar manifestations, i.e. the concentrated nature of economic activity in a number of major urban centres in the country versus the relatively low levels of activity in the remainder of the country. By the 2000s the concentrations had just become much stronger and more established as a key defining feature of the South African space economy. While the endeavours in the $1930 \mathrm{~s} / 1940 \mathrm{~s}$ and the more recent post-apartheid attempts have not made major transformations in the space economy, the 1960s/1970s saw the Apartheid State achieve significant change with its national spatial engineering initiatives in support of its pernicious ideological aims. The authors are of the opinion that the police power of the Apartheid State and the buy in by the white electorate and bureaucracy played a major role in this. This was in all likelihood also supported by a generally favourable perception of the State at the time, long before the advent of the postmodern epoch and its endemic suspicion of the State and all its apparatuses (ibid). Oranje and Merrifield $[7,8]$ conclude that historically therefore it seems that the key drivers to the success of "desired" outcomes in spatial planning initiatives were:

- Establishment of clear policy intent and commitment to make it succeed

- Strong political drive within the governing party and a champion with support of a broad group of stakeholders

- Legal backing, such as in the form of the very powerful Physical Planning Act, 1967, and

- A supportive funding regime and the mobilisation of all the required resources available to the State.

In South Africa, there are a wide array of policy and legal instruments that provide the basis for determining an overarching vision for spatial planning and the desired outcomes at various levels of planning. A preoccupation and running policy theme is the objective of reconfiguring the legacy of the apartheid spatial relations by implementing spatial priorities that meet the constitutional imperative of providing basic services to all and alleviating poverty and inequality. The constitution provides the foundational principles of a socially and economically inclusive South Africa with promotion of socio-economic rights and the protection of the environment as key imperatives that require a response from spatial planning.

Evidently South Africa's unique challenges of uneven spatial development, urban and rural fragmentation and residential segregation require a tailored approach to the formulation of performance indicators.

\subsection{Policy, Legislative and Institutional Environment}

National policy and legislative instruments such as National Development Plan Vision 2030 [9], the New Growth Path [10] and Spatial Planning, Land Use and Management Act (SPLUMA) [11] echo similar themes of inclusive socio-economic development as well as the need for environmental protection. The NDP provides the vision for sustainable development for the country and commits to the elimination of poverty and inequality by 2030 underpinned by efforts to proactively transform the space economy. SPLUMA sketches a normative framework upon which key results areas for spatial planning can be determined. It examines the spatial dimensions of social exclusion and inequality, recognising the burden that unequal and inefficient spatial arrangements place on communities. It also provides the legal framework for spatial planning principles that should lead to outcomes that are consistent with precepts encapsulated in the Constitution. Among others, SPLUMA objectives include the redress of spatial injustices and the attendant development imbalances. It further identifies the need to correct the process and effects of existing spatial planning approaches that exclude the poor from the fruits of development. In the same vein, the New Growth Path Framework (NGP) sets ambitious targets in terms of inclusive growth by seeking to foster a high-employment economy that delivers on social and spatial cohesion. By reviewing the legislative and policy environment, a sketch of the desired spatial planning outcomes begins to take shape, namely:

- Redress of historical spatial imbalances

- Use of space to deliver on equitable development

- Access to productive assets such as land and capital, and

- Spatial inclusivity and sustainability.

In this regard, the White Paper on Spatial Planning and Land Use Management [7] enumerated key principles underpinning desired spatial planning outcomes. The White Paper states that the basis of spatial planning and land-use management will be principles and norms aimed at achieving sustainability, equality, efficiency, fairness and good governance.

By definition, delivery of spatial planning outcomes is heavily reliant upon the actions of a plurality of actors and agencies across different operationally independent policy sectors. In South Africa, the horizontal axis of spatial interaction is intersected by the vertical complexity of activities across the different spheres of government. Thus, the implementation of spatial planning objectives is not only highly dependent upon the coordinating role of national government, but also local support in the interpretation of such policy guidance. The need for institutional integration and policy alignment to achieve coherent spatial planning 
outcomes has been a running theme in several policy initiatives in South Africa.

In addition, the Medium-Term Strategic Framework (MTSF) defines twelve outcomes of the South African government, which in turn, were derived from the ruling party's 2009 Election Manifesto. While the MTSF covers a five-year time frame, the twelve outcomes have longer-term horizons, covering issues such as improved education, health, safety, employment, skills, economic infrastructure, vibrant rural communities, sustainable human settlements, responsive local government, enhanced natural resources, developmental public service and empowered citizenship [12]. Each outcome contains several outputs and activities to enable more frequently monitoring of performance. For example, Outcome 8 is about building sustainable communities and improving the quality of household life complete with four associated outputs expressed as targets [12]:

- Accelerate the delivery of housing opportunities by, for example, upgrading 400000 informal settlements in four years as well as delivering 80000 affordable rental houses

- Improve access to basic services (water from $92 \%$ to $100 \%$, sanitation from $69 \%$ to $100 \%$, refuse removal from $64 \%$ to $75 \%$, electricity from $81 \%$ to $92 \%$ )

- Mobilise well-located public land for low income and affordable housing (release 6250 hectares over four years and achieve densities of 60 units per hectare), and

- Improve the property market by financing 600,000 housing opportunities in the gap market.

\subsection{International Experience}

Internationally, current spatial planning paradigms represent a shift from the old 'plan-present-defend' approach to one that places more emphasis on partnership working and consensus building [13]. In the era of the 'network society', there is a call for a more flexible and pluralistic view of planning. This means that effective plans that contribute to wider outcomes need to be assessed, in part at least, on their ability to be flexible and adaptable. Process efficiency is seen as being central to delivering the outcomes consistent with visions of sustainable communities and democratic norms.

Serbia: Spatial planning outcome and output indicators set in Serbia are the result of a multi-level selection process. The criteria for the evaluation of an output framework include [14]: (i) connection with objectives and priorities of strategic spatial development of Serbia; (ii) reliable measuring possibilities; (iii) durability; (iv) relevance to space creation, use and management; (iv) collected on a regular basis by statistical data sources and (v) synchronized with European Spatial Planning Observatory Network (ESPON) indicators.

United Kingdom (UK): A fixed set of indicators in the SPO framework serve to provide a strong platform for stakeholders to develop their own frameworks. Overall SPO indicators developed subscribe to the following minimum requirements:

- Should be transferable across the UK and form a strong backbone to link up with other sectoral policy monitoring in the country and different regions that constitute the UK and, by extension, the EU region.

- Less focus on single indicator values, but more about how to flexibly combine indicators to yield meaningful policy intelligence.

- Includes 'spatiality' in the analysis by emphasising the importance of functional areas and spatial linkages and connections.

- $\quad$ Focus on making use of indicators to help planners and key stakeholders to question the values, assumptions, and core strategies that led to the policy actions in the first place and will then be able to modify policy and actions to address the new issues identified, and

- Provides a communicative and iterative learning approach through monitoring and embeds monitoring right at the heart of the policymaking process.

A strong point about the UK SPO framework is that individual indicators are not intended for use in an isolated fashion, but rather within an integrative framework which views them as parts of a whole, rather than separate entities [15]. Similarly, the framework views individual locations as parts of a wider spatial context rather than isolated locations (ibid).

In many countries, and as is the case in South Africa, spatial planning levels vary, and accordingly different spatial planning policy instruments are required to address specific policy requirements of each level. In terms of the various levels of planning, the local and sub-regional levels can legitimately be viewed as the area where outputs of spatial planning are located, while regional and national level areas are where spatial planning outcomes are realized. In South Africa, policy performance measurement is the norm for the various spheres of government. Thus, crafting and on-ramping the SPO measurement framework into the existing performance systems such as strategic plans and annual performance plans are unlikely to be onerous tasks.

\section{Findings and Results}

\subsection{Approaches to Measuring Spatial Planning Outcomes}

Approaches for measuring spatial outcomes should take into consideration the specified vision and objectives of the plan. In other words, the eventual assessment should take measurement of a spatial development vision based on promising opportunities and high, but realistic ambitions, which are supported by diverse groupings of society. Since spatial plan is an integrative plan, the approach for measuring its outcome should also be integrative, by measuring the effectiveness of the integral parts of the plan. 
For the UN [16] the measurement of spatial planning outcomes can be based on the nature of benefits e.g. economic, social and environmental benefit in response to sustainable spatial development requirement. Tables 1 and 2 profile two measurement approaches that have been adopted with a view to informing the generation of responsive and appropriate SPOs for South Africa, namely, cumulative and sectoral.

\subsection{Policy, Institutional and Legislative Environment}

Table 3 below enumerates and reviews selected policy, institutional and legislative instruments that impinge and have a bearing on the development of an SPO Measurement Framework, complete with its indicator set.

Table 1. Spatial Planning Cumulative Measurement Approaches

\begin{tabular}{|c|c|}
\hline $\begin{array}{l}\text { Cumulative Measurement } \\
\text { Approach }\end{array}$ & Description \\
\hline $\begin{array}{l}\text { Measuring anticipated (planned) } \\
\& \text { achieved spatial development } \\
\text { of the regions }\end{array}$ & $\begin{array}{l}\text { This will require measuring of the difference of what has been achieved in comparison to the plan's desires } \\
\text { in a given time-frame. This may involve measuring how a spatial plan addresses structural balances in } \\
\text { regions or at local scale. }\end{array}$ \\
\hline Sustainability approach & $\begin{array}{l}\text { Sustainability concerns is present today as a core policy not only in leading international organizations (such } \\
\text { as the UN \& the EU), but also in most national, regional \& local institutions throughout the world [17]. It is } \\
\text { used as a measure of any exercise including planning so long as the aim is to attain good \& positive results. } \\
\text { The interrelationship between sustainable development (SD) \& spatial planning was foreshadowed in the } \\
\text { Brundtland Commission Report [18]. The notion of sustainability has penetrated \& permeated national } \\
\text { spatial planning systems, \& shapes conceptual principles, organizational patterns, policy priorities, practices } \\
\& \text { plans at all administrative tiers. }\end{array}$ \\
\hline Integrity of the spatial structure & $\begin{array}{l}\text { A good measure of spatial plan should anticipate higher integration of the structure of the plan \& governance } \\
\text { of the plan e.g. connecting with neighbouring areas, ecosystem as a component of the spatial structure, } \\
\text { openness to post planning development, relating national to regional \& local institutions mandated to } \\
\text { coordinate, prepare \& implement spatial plans }\end{array}$ \\
\hline Multi-level governance approach & $\begin{array}{l}\text { A multi-level governance approach would offer the potential to tease out causal linkages between global, } \\
\text { national, regional, metropolitan \& local change, while also taking account of the highly diverse outcomes of } \\
\text { such interactions. }\end{array}$ \\
\hline $\begin{array}{l}\text { Ability to map out disasters \& } \\
\text { general risks }\end{array}$ & $\begin{array}{l}\text { Good spatial plan should be based on geological, morphological and seismological studies which gives an } \\
\text { informed analysis on the vulnerability of the planning area. This should facilitate development of appropriate } \\
\text { mitigation measures or creating resilience by balancing risks. }\end{array}$ \\
\hline Liveability approach & $\begin{array}{l}\text { Aims at measuring how environmental management and planning combine in order to improve the quality of } \\
\text { life for citizens e.g. attaining the smart growth principles by providing for greater certainty for the location } \\
\& \text { sequencing of growth, \& strengthened alignment of land use, transport \& economic development. }\end{array}$ \\
\hline Scenario \& forecasting approach & $\begin{array}{l}\text { Ability of the plan to identify existing \& future locations \& mix of various land uses with certainty or } \\
\text { negligible error within specific geographic areas of the plan }\end{array}$ \\
\hline Enabling approach & $\begin{array}{l}\text { Supporting decisions made by the Government \& other parties, e.g. about land use, transport \& location of } \\
\text { education \& other facilities, etc. }\end{array}$ \\
\hline Investment approach & $\begin{array}{l}\text { Provide greater certainty to the private sector - refers to the ability of a spatial plan to achieve } \& \text { direct } \\
\text { investments }\end{array}$ \\
\hline
\end{tabular}

Table 2. Spatial Planning Cumulative Measurement Approaches

\begin{tabular}{|c|l|}
\hline Sectoral Measurement Approach & \multicolumn{1}{c|}{ Description } \\
\hline Economic Development & $\begin{array}{l}\text { At a societal or collective level, it aims to improve economic conditions. The impact of the spatial plan on } \\
\text { employment opportunities \& the quality of life by creating more investment opportunities \& markets for } \\
\text { products is another approach of measuring planning outcomes. It also should balance any displacement } \\
\text { brought about by development or activities undertaken within a specified area. Other related measures which } \\
\text { may be considered under economic development include competitiveness, revitalization, entrepreneurship, } \\
\text { food security \& culture. }\end{array}$ \\
\hline $\begin{array}{c}\text { Infrastructure \& communal } \\
\text { systems provisions }\end{array}$ & $\begin{array}{l}\text { Spatial plan outcomes can be measured on how it addresses various infrastructural concerns of an area e.g. } \\
\text { road, rail \& air, telecommunication, water services, waste management \& sustainable energy }\end{array}$ \\
\hline $\begin{array}{c}\text { Demographic changes \& spatial } \\
\text { structure }\end{array}$ & $\begin{array}{l}\text { Appraisal of the state of demographic changes and how the projections fit within the projected spatial } \\
\text { development in terms of response to population needs such as health \& educational facilities among others }\end{array}$ \\
\hline $\begin{array}{c}\text { Natural Values \& cultural } \\
\text { heritage }\end{array}$ & Measured in terms of how natural areas such as parks, rivers \& cultural heritage have been protected \\
\hline
\end{tabular}


Table 3. Selected policy, institutional and legislative instruments

\begin{tabular}{|c|c|}
\hline $\begin{array}{r}\text { Policy / } \\
\text { Legislation }\end{array}$ & Description \& Implication for Spatial Planning \\
\hline $\begin{array}{l}\text { Constitution of } \\
\text { South Africa } \\
\quad(1996)\end{array}$ & $\begin{array}{l}\text { The Constitution has a bearing on the planning system in that new constitutional requirement such as cooperative governance, } \\
\text { procedural \& participatory rights to ensure accountability for decision-making, the promotion of social \& economic rights \& the } \\
\text { protection of the environment create imperatives that profoundly affect planning. The new constitutional model redefines the } \\
\text { relationships between government, by replacing the system of a vertical hierarchy of tiers with three overlapping planning } \\
\text { processes \& sets of plans, each relating to a different sphere of government. National legislation deals with a matter that, to be } \\
\text { dealt with effectively, requires uniformity across the nation, \& the national legislation provides that uniformity by establishing } \\
\text { (i) norms \& standards; (ii) frameworks or (iii) national policies. National legislation is necessary for the maintenance of } \\
\text { economic unity \& the protection of the environment. }\end{array}$ \\
\hline $\begin{array}{l}\text { National } \\
\text { Development } \\
\text { Plan: Vision } \\
2030(2012)\end{array}$ & $\begin{array}{l}\text { The National Development Plan aims to eliminate poverty \& reduce inequality by } 2030 \text {. To eliminate poverty \& reduce } \\
\text { inequality, the economy must grow faster and in ways that benefit all South Africans. The NDP is based on the following broad } \\
\text { principles within which specific actions \& strategies are developed by government, namely: } \\
\text { An economy that will create jobs; Improving Infrastructure; Transition to a low carbon economy; An inclusive \& integrated rural } \\
\text { economy; Reversing the spatial effects of Apartheid; Improving the quality of education, training \& innovation; Quality } \\
\text { healthcare for all; Social protection; Building safer communities; Reforming the Public Service, and Fighting corruption. } \\
\text { The above principles of the NDP in essence encapsulate in a very wide context possible objectives of a spatial framework. }\end{array}$ \\
\hline $\begin{array}{l}\text { New Growth } \\
\text { Path Framework } \\
\quad(2011)\end{array}$ & $\begin{array}{l}\text { There is growing consensus that creating decent work, reducing inequality \& defeating poverty can only happen through a new } \\
\text { growth path founded on a restructuring of the South African economy to improve its performance in terms of labour absorption } \\
\text { as well as the composition \& rate of growth. The strategy sets out critical markers for employment creation \& growth \& } \\
\text { identifies where viable changes in the structure \& character of production can generate a more inclusive \& greener economy over } \\
\text { the medium to long run. It combines macroeconomic \& microeconomic interventions. It takes account of the new opportunities } \\
\text { that are available to, the strengths the constraints. It carries the strong echoes of equity that are voiced in other policy documents. } \\
\text { Amongst other decisions, it says the government must prioritise its own efforts and resources more rigorously to support } \\
\text { employment creation and equity. The document knits together the Industrial Policy Acton Plan2 (IPAP) as well as policies and } \\
\text { programmes in rural development, agriculture, science \& technology, education \& skills development, labour, mining \& } \\
\text { beneficiation, tourism, social development \& other areas. }\end{array}$ \\
\hline $\begin{array}{l}\text { Spatial Planning } \\
\text { \& Land Use } \\
\text { Management } \\
\text { Act (2013) }\end{array}$ & $\begin{array}{l}\text { Spatial Planning \& Land Use Management Act (SPLUMA, 2013) is framework act for all spatial planning \& land use } \\
\text { management legislation in South Africa. It seeks to promote consistency \& uniformity in procedures \& decision-making in this } \\
\text { field. The other objects include addressing historical spatial imbalances \& the integration of the principles of sustainable } \\
\text { development into land use \& planning regulatory tools \& legislative instruments. }\end{array}$ \\
\hline $\begin{array}{l}\text { Development } \\
\text { Facilitation Act } \\
\text { (DFA) (1995) }\end{array}$ & $\begin{array}{l}\text { The DFA shifted spatial planning from a control orientation towards being normatively-based. This means that the law } \\
\text { introduces substantive principles (norms) that must guide land development \& decision-making. In addition to principles, the } \\
\text { DFA introduced the concept of land development objectives (LDOs). These are plans approved by political decision-makers that } \\
\text { set their objectives \& targets for development \& which inform the spatial \& developmental imperatives of an area. These policy } \\
\text { plans (which can also be referred to as integrated development plans) are also normative in that they set out desired aims. } \\
\text { Normative legislation calls for a proactive planning system which places emphasis on considered judgements \& the discretion of } \\
\text { decision makers, as opposed to the application of standardised rules \& regulations. }\end{array}$ \\
\hline $\begin{array}{l}\text { Municipal } \\
\text { Systems Act } 32 \\
\quad \text { of } 2000\end{array}$ & $\begin{array}{l}\text { Chapter } 5 \text { provides for the preparation of IDPs: } \\
\text { Section } 26(\mathrm{e}) \text { lists an SDF as a core component of an IDP \& requires that the spatial plan provides basic guidelines for a } \\
\text { municipal land use management system } \\
\text { Section } 24(1) \text { requires that municipalities should align their planning with national \& provincial planning, as well as those of } \\
\text { affected municipalities } \\
\text { Section } 27 \text { requires a district municipality to adopt a framework for integrated development planning that is binding to the local } \\
\text { \& district municipality. } \\
\text { This framework should: } \\
\text { Identify relevant national and provincial legislation, } \\
\text { Identify matters that require alignment between local and district planning } \\
\text { Specify principles to be applied } \\
\text { Determine procedures for coordination \& amendment of the framework }\end{array}$ \\
\hline $\begin{array}{l}\text { Spatial } \\
\text { Development } \\
\text { Initiatives } \\
\text { (SDIs) }\end{array}$ & $\begin{array}{l}\text { The Department of Trade \& Industry's spatial development initiatives (SDIs) \& its proposed industrial development zone (IDZ) } \\
\text { policy are important national development initiatives, with potentially enormous spatial impacts. However, these have generally } \\
\text { been poorly coordinated with provincial \& local plans. }\end{array}$ \\
\hline $\begin{array}{l}\text { National Spatial } \\
\text { Development } \\
\text { Perspective } \\
\quad(2006)\end{array}$ & $\begin{array}{l}\text { Government policy (albeit failed to find traction in terms of implementation) that recognizes the importance of the space } \\
\text { economy in addressing the legacy of Apartheid \& provides guiding principles for the space economy as follows: } \\
\text { All people have a right to basic services (wherever they reside) } \\
\text { Fixed investment should be direct to areas with economic \& employment growth potential } \\
\text { Social inequalities should be addressed through investment in people rather than places } \\
\text { Future settlement \& development opportunities should be channelled to nodes \& corridors related to major growth centres }\end{array}$ \\
\hline $\begin{array}{l}\text { White Paper on } \\
\text { Local } \\
\text { Government }\end{array}$ & $\begin{array}{l}\text { Whilst existing government policy provides a great range of inputs for planning and development, the White Paper on Local } \\
\text { Government is critical as it places municipalities at the centre of planning for better human settlements. The new municipal } \\
\text { planning system is founded on the concept of 'developmental local government'. It emphasises integrated development planning } \\
\text { as a tool for realising the vision of developmental local government. }\end{array}$ \\
\hline $\begin{array}{c}\text { Urban \& Rural } \\
\text { Development }\end{array}$ & $\begin{array}{l}\text { The Urban Development Framework (1995) published by the Department of Housing, examined the dilemmas \& realities facing } \\
\text { South Africa's urban areas. It provided a positive \& common vision, albeit at a very general level, of a desired future for South }\end{array}$ \\
\hline
\end{tabular}




\begin{tabular}{|c|c|}
\hline $\begin{array}{r}\text { Policy / } \\
\text { Legislation }\end{array}$ & Description \& Implication for Spatial Planning \\
\hline Frameworks & $\begin{array}{l}\text { Africa's urban areas in the year 2020. The Rural Development Framework, published by DRDLR, described how government } \\
\text { aims to achieve a rapid \& sustainable reduction in absolute rural poverty. }\end{array}$ \\
\hline $\begin{array}{l}\text { Provincial } \\
\text { planning \& } \\
\text { development } \\
\quad \text { laws }\end{array}$ & $\begin{array}{l}\text { Many provinces have been reformulating their planning \& development laws in an attempt to create legal uniformity \& to redress } \\
\text { the apartheid legal \& administrative chaos. KwaZulu-Natal, the Western Cape \& the Northern Cape have passed new laws, \& } \\
\text { Gauteng is near to passing one as well. In all four cases, the paradigm ushered in by the DFA of normatively-based legislation } \\
\text { has been followed with some provincial nuances. The other provinces are all intending to follow suit. The problem with the } \\
\text { provincially led law reform process is that each province is pursuing its processes independently of the others, \& in the absence } \\
\text { of national guidelines other than the DFA in its current form \& certain gaps \& inconsistencies have inevitably crept in. }\end{array}$ \\
\hline Sectoral laws & $\begin{array}{l}\text { In addition, a number of new laws with powerful implications for planning such as the National Environmental \& Management } \\
\text { Act, the Housing Act, the Water Services Act, the regulations passed in terms of the Environmental Conservation Act, have been } \\
\text { enacted that superimpose a powerful set of procedural obligations on other spheres of government, especially local government. }\end{array}$ \\
\hline $\begin{array}{l}\text { Other Relevant } \\
\text { Frameworks }\end{array}$ & $\begin{array}{l}\text { Other national departments, such as Human Settlements, Water \& Environmental Affairs \& Transport have developed policies } \\
\text { that have spatial impacts and impact on planning \& development. Some of these have been expressed in new regulations \& } \\
\text { legislation referred to above \& has significant impact on provincial, but particularly local-scale planning. There is also a variety } \\
\text { of other policy initiatives that have relevance in the spatial planning context. For example, policy with respect to land tenure will } \\
\text { in the long-term greatly affect the security with which land is allocated, occupied \& used in large parts of the country. Funding } \\
\text { policies for municipal infrastructure \& housing have strong impact on settlement planning, \& are increasingly being brought into } \\
\text { the integrated planning system. Transport subsidy policy has impact on people's choices of residential location, \& the } \\
\text { Department of Transport aims to alter these policies in order to reduce the costs of transport subsidies to the national treasury. } \\
\text { Cabinet has recognised the importance of the spatial implications of various national policies, \& has given the Coordination \& } \\
\text { Implementation Unit in the Executive Deputy President's office (CIU) the task of developing guidelines for more effective } \\
\text { spatial alignment of public programmes \& projects. }\end{array}$ \\
\hline $\begin{array}{l}\text { Medium-Term } \\
\text { Expenditure } \\
\text { Framework } \\
\text { (MTEF) }\end{array}$ & $\begin{array}{l}\text { The MTEF requires the formulation of departmental budgets on a rolling three year basis. This should permit greater levels of } \\
\text { predictability, thereby potentially enhancing the planning system. It also provides an important component of a new planning } \\
\text { system which ensures that plans \& budgets are linked to one another. }\end{array}$ \\
\hline
\end{tabular}

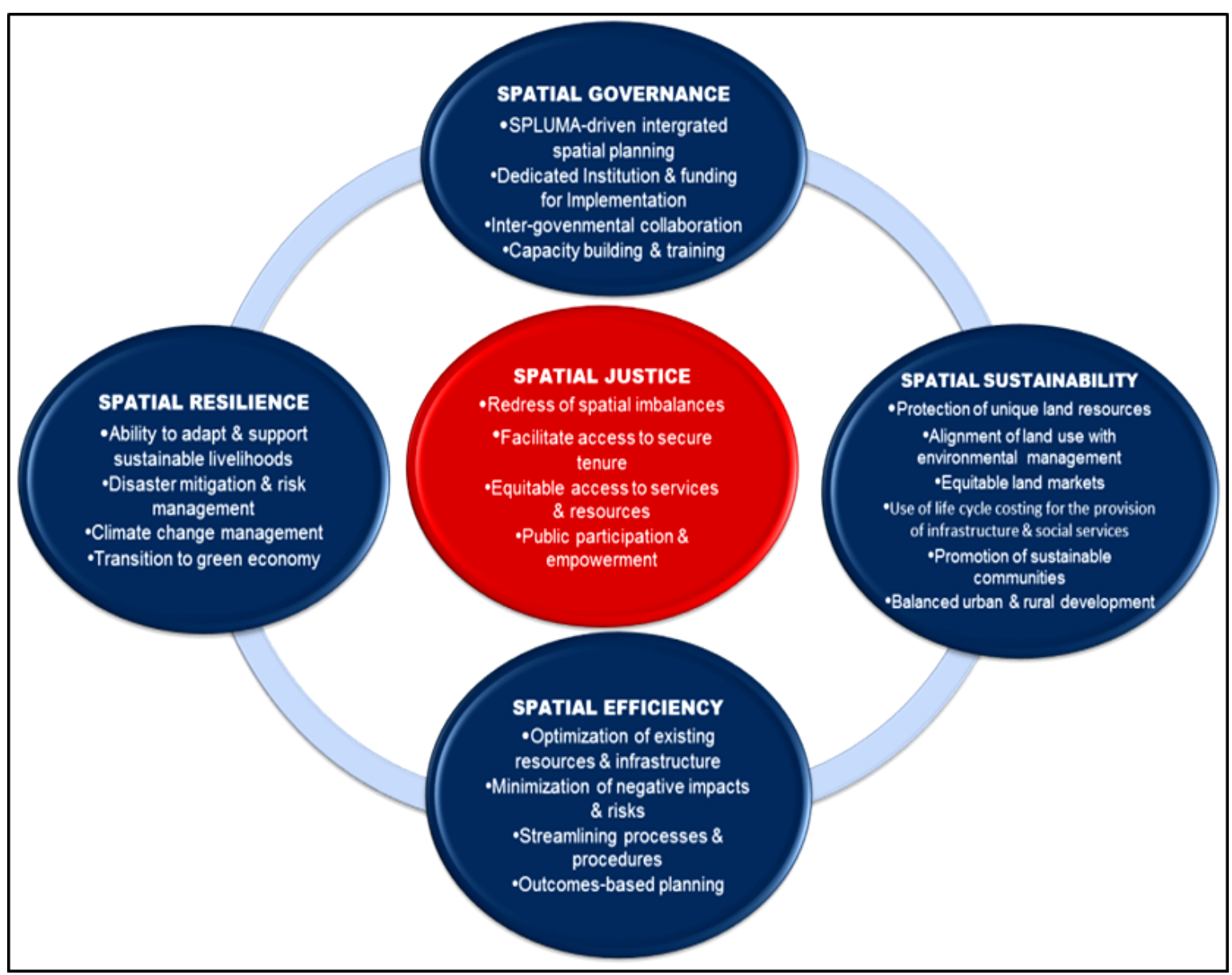

Figure 2. SPLUMA-informed Spatial Planning Outcomes Measurement Principles/Pillars 


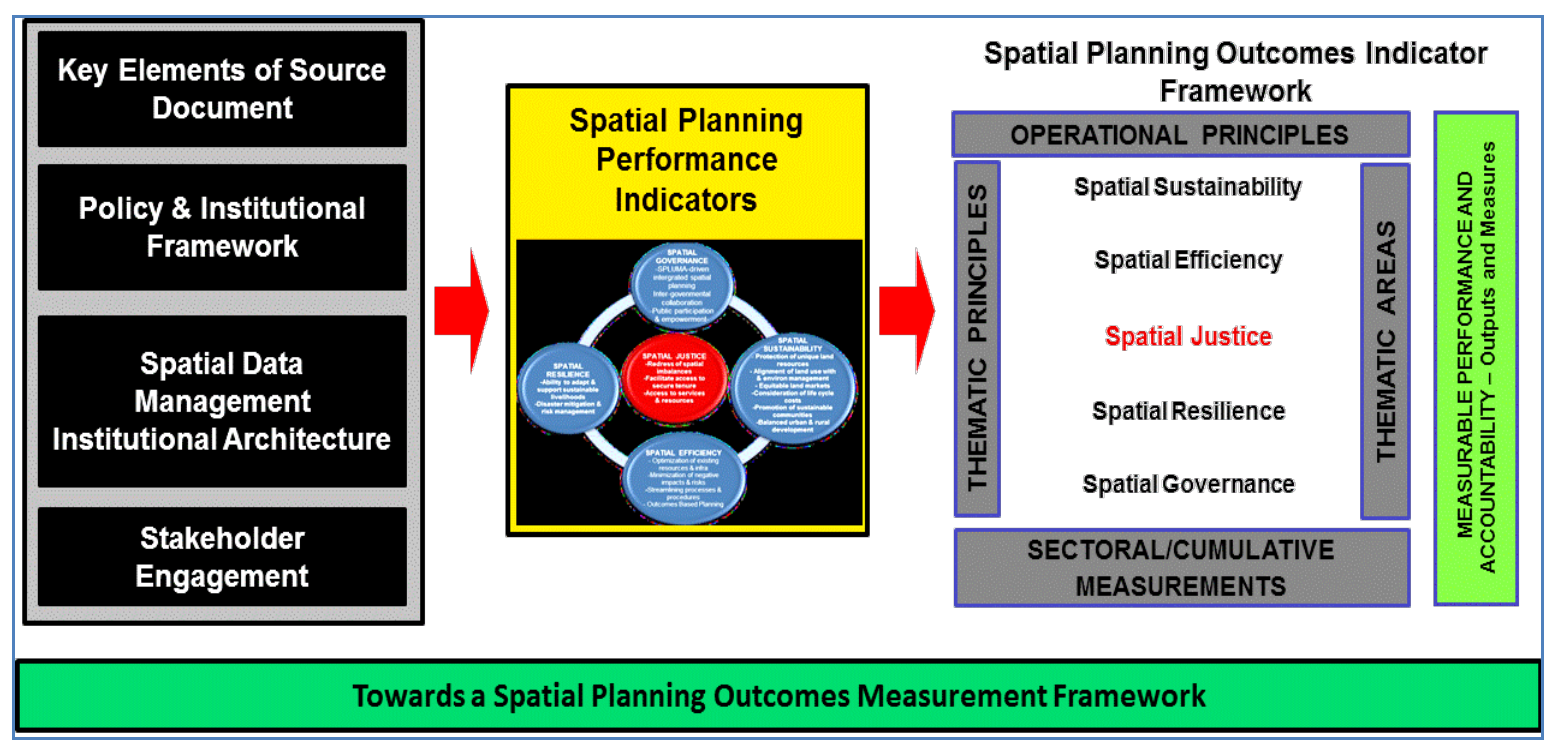

Figure 3. Road map to SPO Measurement Indicator Framework

It is germane to note here that the continued existence and operation of multiple laws at national and provincial spheres of government in addition to the laws applicable in the previous homelands and self-governing territories have created fragmentation, duplication and often unfair discrimination. Some urban and rural areas currently do not have any applicable spatial planning and land use management legislation and are therefore excluded from the benefits of spatial development planning and land use management systems. The various laws governing land use give rise to uncertainty about the status of municipal spatial planning and land use management systems and procedures and frustrate the achievement of cooperative governance and the promotion of public interest. Currently, all areas under informal and traditional land use development processes are poorly integrated into formal systems of spatial planning and land use management. Table 3 has presented a summary of the legal frameworks with implications for SPO in South Africa.

\subsubsection{Existing Mechanisms for Spatial Planning Performance Evaluation in South Africa}

Integrated Development Plan (IDP): The IDP is the principal strategic planning instrument which guides and informs all decisions with regard to planning, management and development in a municipality. The IDP process is intended to have a committed expenditure program by the local authority in support of its identified developmental goals and objectives. A key component of the IDP is the spatial development framework, which must set objectives that reflect the desired spatial form of a municipality. The IDP process thus ensures the dovetailing of the spatial framework and the planned institutional and budgetary allocations. This requirement provides for a broad and descriptive framework that only allows for limited evaluation - specific outcomes are not adequately measured.

Spatial Planning and Land Use Management Act (2013):
The Act represents a definitive shift to normative planning which aims to provide for a uniform, recognisable and comprehensive system of spatial planning and land use management throughout South Africa to ensure economic unity, equal opportunity and equal access to socio-economic opportunities.

Internal performance measurement practices: Local governments in South Africa have established internal performance management and monitoring systems (which have been rapidly evolving for the better) designed to routinely assess, for example, performance in delivering services, infrastructure and housing through extensive existing indicators. These processes are undergirded by a legislatively mandated set of instruments, including IDPs, Medium-Term Revenue and Expenditure Frameworks (MTREFs), and Service Delivery and Budget Implementation Plans (SDBIPs). They also do this at the behest of national and provincial departments in order to comply with regulatory requirements, such as the performance management system in the Municipal Systems Act (MSA, 2000), or to report on resource allocation and impacts such as the Municipal Finance Management Act (MFMA, 2003) in-year and annual reporting requirements on financial and non-financial information. They are also required to measure performance against specified indicators to qualify for specific grants, such as the Urban Settlements Development Grant (USDG) (for land and infrastructure) and the Human Settlements Development Grant (HSDG) (for housing top structures).

\subsection{Summary Responses of the Stakeholder Engagement Process}

Municipalities view the preparation of SDFs as crucial to the sustainable growth and development of the municipal area supported by a strong vision undergirded by robust spatial principles operating within the ambit of national policies and legislation [5]. Intuitively, most municipalities 
singled out and highlighted the attraction of investment and development as the defining role of SDFs. However, the absence of a mechanism to measure these specific outcomes identified in the SDF was thus considered a major stumbling block to understanding the efficacy and potency of this delivery instrument. The consultative and iterative development of a robust Measurement Framework complete with suite of appropriate indicators and supported by measurement guidelines that establish horizontal and vertical coordination between spheres of government underpinned by institutional support and access to information and communication tools was thus considered a logical, pivotal and welcome development.

In addition, while most municipalities favoured the development of an "objective derived" outcome indicator framework largely because it is less rigid and tends to assist in unpacking the purpose of the SDF, the interrelationship between "objective derived" and "plan derived" approaches was considered crucial to understanding the spatial planning outcomes of administrative and functional areas covered by an SDF.

\subsection{Towards a Framework for Measuring Spatial Planning Outcomes}

\subsubsection{Cornerstones of a Measurement Framework}

The process of generating an SPO measurement framework is undergirded by three cornerstones, namely [6]:

- Formulation of desired planning outcomes: The first important part of the framework is in the formulation and adoption of the desired spatial planning outcomes. This consists of a clearly articulated spatial vision of the socio-economic and environmental trajectory of the planning system on a national scale in a way that is consistent with national spatial planning objectives as contemplated in SPLUMA.

- Results measurement framework: A performance or results measurement framework is a mechanism that uses objective criteria / indicators to monitor the logical structure of actions and inputs to ensure that they individually and collectively contribute to the desired spatial planning outcomes and impacts.

- Institutional mechanism for managing results delivery: In elaborating the importance of a robust institutional framework for spatial planning outcomes delivery, the lessons from the history of spatial planning in South Africa suggests that spatial planning impacts are highly dependent on a very strong political drive accompanied by the necessary human, technical and financial resources.

\subsubsection{Spatial Planning Outcomes Measurement Pillars/Principles}

In determining the desired spatial planning outcomes for South Africa, SPLUMA [11] is regarded as the foundational document that provides the legal framework for spatial planning principles that are consistent with the tenor of the
Constitution [19]. In broad terms, SPLUMA objectives include the redress of spatial injustices and the integration of socio-economic and environmental considerations in land use management in order to balance current development needs with those of future generations in a transformative manner. SPLUMA reinforces and unifies the vision and policies articulated in the National Development Plan (NDP) and the New Growth Path Framework (NGP) in respect of using spatial planning mechanisms to eliminate poverty and inequality while creating conditions for inclusive growth by seeking to foster a high-employment economy that delivers on social and spatial cohesion. Five development principles that should be applied to spatial planning, land use management and land development in South Africa, which have been eloquently articulated in SPLUMA, have been adopted as the measurement framework's levers and wheels driving the indicator framework, namely:

- $\quad$ Spatial Justice

- Spatial Sustainability

- Spatial Efficiency

- $\quad$ Spatial Resilience, and

- Spatial Governance.

While SPLUMA does not indicate the relational interdependence among the five intertwining principles, it is possible to derive the core elements of desired spatial planning outcomes in South Africa by presenting the principles into a logical relational structure as shown in Figure 2.

As can be surmised from the above, the overarching vision for spatial planning in South Africa is anchored around the principle of Spatial Justice. This fulcrum encompasses the redress of existing spatial imbalances and all notions of inclusion. The spatial justice vision is buttressed by and realised through four key pillars. These are:

- Spatial Resilience: Relates to mitigation, adaptability and innovations to secure communities from spatial dimensions of socio-economic and environmental (climate change) shocks.

- Spatial Sustainability: Relates to the need to promote spatial planning and land use management and land development systems that are based on and promote the principles of socio-economic and environmentally sustainable development.

- Spatial Efficiency: This places significant importance on the optimization of existing resources and the accompanying infrastructure, including the oiling of development application procedures in order to promote growth and employment, and

- Spatial Governance: The spatial governance principle is central to achieving the desired outcomes across the various planning spheres and domains largely because implementation of the spatial planning vision and objectives is not only highly dependent upon a strong coordinating role of national government, but is also predicated upon good governance mechanisms, incorporating meaningful consultations and coordination. 


\subsubsection{Spatial Planning Outcomes Indicator Framework}

In general, spatial planning outcomes should be viewed as the combined effects on socio-economic and environmental changes brought about by the planning system and other forces that seek to achieve sustainable development. In a plan-led system, the outcomes of spatial policies can only be effectively measured and interpreted if the indicators are plan derived (refer to Figure 3). A review of the theoretical and philosophical foundations of spatial planning indicates that spatial planning outcomes can be measured within the purview of the following triumvirate of dimensions, namely:

- Institutional dimension: Sector, organisation, institutional, etc.

- Scale dimension: International, national, regional/provincial, district and local, and

- Impact dimension: Physical, social, economic, environmental and political.

From Figure 3, we can deduce that the proposed SPO Measurement Indicator Framework has incorporated institutional, scale and impact dimensions, which are underpinned by overarching principles of collaboration, integration, connectivity, inclusivity and sustainability. In addition, a three-pronged analytical approach was employed to unravel the range and depth of indicators, as follows:

- Thematic categorization and detailed interpretation of focus areas by sub-themes

- Contextual realities applicable to the level of the spatial development framework in South Africa, and

- Generation of a minimum bundle of measurement criteria by theme, scale and operational unit.

The chosen indicators, which have been crafted to be relatively simple, easy to interpret and responsive to changes, are not only policy relevant, but also provide a holistic snapshot of spatial planning impacts on both the built and non-built environments. Analytically, they easily lend themselves to being linked to spatial, land use, transport, infrastructure, population, economic models, forecasting and information systems. ${ }^{1} \mathrm{~A}$ sample of the outputs is presented in Table 4 and 5. Additionally, Table 4 presents the pillars that define the firmament for measuring spatial planning outcomes together with a suite of headline indicators. In addition, for each of the five pillars representing the key thematic areas and scale dimensions, robust, wide-ranging and inclusive indicators have been generated with a view to improving the monitoring and management of the transformation of spaces, places and cultures for the benefit of all. Table 4 further depicts a measurement matrix illustrating how the measurement framework can be used in practice across the five thematic $\operatorname{areas}^{2}-$ using Spatial
Justice as an example. Table 5 depicts a measurement matrix illustrating how the measurement framework can be used in practice across the five thematic areas - using Spatial Justice as an example. Table 6 presents the spatial planning outcomes indicator framework. This is indexed to municipal, district, provincial, national and international scale. The constant remain the SPLUMA measurement pillars, namely spatial sustainability, spatial efficiency, spatial justice, spatial resilience and spatial governance. Table 7 presents the SPO outcomes measurement matrix making use of the spatial justice as an example.

It is pertinent to emphasize here that the choice of appropriate spatial scales and functional areas is very important in the measurement of spatial outcomes. In spite of the fact that administrative units tend to be used as the spatial entities to deliver planning policy initiatives, they do not define functional entities such as housing and labour market areas or river catchment areas. Thus, seeking to measure the wider outcomes of planning underlines the importance of functionality and, that, different types of functional areas could be used to measure different indicators to yield the best policy intelligence.

It is also important not lose sight of the fact that the key purpose of indicators is to translate complex relationships and phenomena in a way that is easy to understand and provides usable and reliable signals about important spatial development trends over time. Thus, indicators need to be analysed so that decision makers can make an informed choice about whether a specific policy or objective is, or has been, successful or whether it needs to be adapted or even abandoned altogether. Therefore, there is no such thing as a perfect indicator. In order to be effective, indicators need to balance the demands for scientific accuracy underpinned by concise information and the challenges associated with collecting the requisite data.

\subsection{Information for Managing Spatial Development}

Clearly, the provision of information (creating the evidence base) is a critical tool for managing spatial development. However, spatial development trends often manifest over a long period of time and data collection and interpretation can be time and resource intensive. While this SPO monitoring framework seeks to satisfy both the demands for an analytical base for sound spatial analysis, as well as the varying political demands enabling the evaluation of policy strategies and the assessment of the achievement of policy aims, the applicability and usability of the indicators are directly dependent on the quality, quantity and timeliness of data collected.

1 In this article we use spatial justice for illustrative purposes. For the comprehensive coverage of spatial planning outcomes in South Africa, refer to Towards a framework for measuring spatial planning outcomes in South Africa: Draft Final Report that is accessible from the DRDLR, Pretoria, 2014.

2 Spatial sustainability, spatial efficiency, spatial justice, spatial resilience and spatial (good) governance 
Table 4. Spatial Planning Outcomes Measurement Framework Pillars

\begin{tabular}{|c|c|c|c|c|}
\hline \multicolumn{5}{|c|}{ SPATIAL PLANNING OUTCOMES MEASUREMENT FRAMEWORK PILLARS/THEMATIC AREAS } \\
\hline $\begin{array}{c}\text { SPATIAL } \\
\text { SUSTAINABILITY }\end{array}$ & SPATIAL EFFECIENCY & $\begin{array}{l}\text { SPATIAL } \\
\text { JUSTICE }\end{array}$ & $\begin{array}{c}\text { SPATIAL } \\
\text { RESILIENCE }\end{array}$ & SPATIAL GOVERNANCE \\
\hline $\begin{array}{l}\text { Generate a long-term spatial } \\
\text { development vision statement } \\
\text { for the municipal area }\end{array}$ & Adopt outcome-based planning & $\begin{array}{l}\text { Redress spatial } \\
\text { \& other } \\
\text { imbalances } \\
\text { through access } \\
\text { to \& use of land. }\end{array}$ & $\begin{array}{l}\text { Ability \& } \\
\text { flexibility to } \\
\text { adapt \& } \\
\text { support } \\
\text { sustainable } \\
\text { livelihoods }\end{array}$ & $\begin{array}{l}\text { Ensure SPLUMA-driven } \\
\text { integrated spatial planning }\end{array}$ \\
\hline $\begin{array}{c}\text { Prepare strategic spatial } \\
\text { development plans (vertical } \\
\text { integration) }\end{array}$ & Streamline processes \& procedures & $\begin{array}{l}\text { Facilitate the } \\
\text { inclusion of all } \\
\text { persons \& areas }\end{array}$ & $\begin{array}{l}\text { Mitigation of } \\
\text { potential } \\
\text { economic \& } \\
\text { environmental } \\
\text { shocks }\end{array}$ & $\begin{array}{l}\text { Establish dedicated directorate / } \\
\text { institution for SPLUMA } \\
\text { implementation }\end{array}$ \\
\hline $\begin{array}{l}\text { Promote sustainable land } \\
\text { development that is in line } \\
\text { with the approved IDP. }\end{array}$ & $\begin{array}{l}\text { Indicate desired \& intended land use } \\
\text { development patterns }\end{array}$ & $\begin{array}{l}\text { Facilitate access } \\
\text { to secure forms } \\
\text { of tenure. }\end{array}$ & $\begin{array}{l}\text { Incorporate } \\
\text { disaster } \\
\text { mitigation \& } \\
\text { risk } \\
\text { management }\end{array}$ & $\begin{array}{l}\text { Prioritise inter-governmental } \\
\text { collaboration - sector inputs \& } \\
\text { compliance with any other } \\
\text { prescribed requirements } \\
\text { (horizontal \& vertical alignment) }\end{array}$ \\
\hline $\begin{array}{l}\text { Align land use management } \\
\text { systems with environmental } \\
\text { management instruments }\end{array}$ & $\begin{array}{l}\text { Optimise the use of existing resources } \\
\qquad \& \text { infrastructure }\end{array}$ & $\begin{array}{c}\text { Land use } \\
\text { management } \\
\text { systems to } \\
\text { facilitate } \\
\text { all-inclusiveness } \\
\text { with provisions } \\
\text { that are fair, just } \\
\& \text { flexible \& } \\
\text { appropriate for } \\
\text { the management } \\
\text { of } \\
\text { disadvantaged } \\
\text { areas }\end{array}$ & $\begin{array}{c}\text { Provide a } \\
\text { strategic } \\
\text { assessment of } \\
\text { the } \\
\text { environmental } \\
\text { pressures \& } \\
\text { opportunities } \\
\text { within the } \\
\text { municipal } \\
\text { area }\end{array}$ & $\begin{array}{l}\text { Facilitate enhanced multi-level } \\
\text { governance }\end{array}$ \\
\hline $\begin{array}{l}\text { Enhance equitable land } \\
\text { markets }\end{array}$ & $\begin{array}{l}\text { Minimise negative impacts \& risks } \\
\text { (financial, social, economic or } \\
\text { environmental impacts) }\end{array}$ & $\begin{array}{l}\text { Foster equitable } \\
\text { access to } \\
\text { services \& } \\
\text { resources }\end{array}$ & $\begin{array}{l}\text { Ability to } \\
\text { adapt to } \\
\text { changes }\end{array}$ & $\begin{array}{l}\text { Embark on skills enhancement \& } \\
\text { capacity building }\end{array}$ \\
\hline $\begin{array}{l}\text { Employ life cycle costing for } \\
\text { the provision of infrastructure } \\
\& \text { social services }\end{array}$ & Limit urban sprawl & \multirow{5}{*}{$\begin{array}{l}\text { Ensure public } \\
\text { participation \& } \\
\text { empowerment } \\
\text { pertaining to } \\
\text { policies, } \\
\text { legislation \& } \\
\text { procedures }\end{array}$} & $\begin{array}{c}\text { Incorporate } \\
\text { relevant } \\
\text { national } \\
\text { development } \\
\text { strategy \& } \\
\text { programme } \\
\text { spatial aspects }\end{array}$ & $\begin{array}{l}\text { Provide a framework for } \\
\text { coordinating Municipal Spatial } \\
\text { Development Frameworks }\end{array}$ \\
\hline $\begin{array}{c}\text { Promote inclusive \& } \\
\text { sustainable land development } \\
\& \text { communities }\end{array}$ & \multirow{4}{*}{ Strengthen corridor developments } & & $\begin{array}{l}\text { Align with } \\
\text { environmental } \\
\text { legislation }\end{array}$ & $\begin{array}{l}\text { Align with national \& provincial } \\
\text { policies, priorities, plans \& } \\
\text { planning legislation }\end{array}$ \\
\hline Protect unique land resources & & & $\begin{array}{l}\text { Engage in } \\
\text { sustainable } \\
\text { development }\end{array}$ & $\begin{array}{l}\text { Develop a dedicated } \\
\text { implementation \& funding } \\
\text { framework }\end{array}$ \\
\hline $\begin{array}{c}\text { Balance urban \& rural } \\
\text { development \& indicate } \\
\text { desired land use patterns }\end{array}$ & & & \multirow{2}{*}{$\begin{array}{l}\text { Promote a } \\
\text { green } \\
\text { economy }\end{array}$} & \multirow{2}{*}{$\begin{array}{l}\text { Determine a spatial capital } \\
\text { expenditure framework for the } \\
\text { development programmes }\end{array}$} \\
\hline Implement SMART growth & & & & \\
\hline
\end{tabular}


Table 5. Reduction of Spatial Justice to implementable scales and impact dimensions ${ }^{3}$

\begin{tabular}{|c|c|c|c|c|c|}
\hline \multirow{2}{*}{ SPATIAL JUSTICE } & \multicolumn{5}{|c|}{ CONTEXTUAL REALITIES (APPLICABLE TO SDFS) } \\
\hline & NATIONAL & PROVINCIAL & REGIONAL & MUNICIPAL & INDICATORS \\
\hline $\begin{array}{l}\text { Redress spatial \& other } \\
\text { imbalances through } \\
\text { improved access to \& } \\
\text { use of land }\end{array}$ & $\begin{array}{l}\text { - Enhance spatial coordination } \\
\text { of land development \& land } \\
\text { use management activities at } \\
\text { national level; } \\
\text { - Coordinate \& integrate } \\
\text { provincial \& municipal spatial } \\
\text { development frameworks } \\
\text { - Indicate desired patterns of } \\
\text { land use in the Republic } \\
\text { - Promote an inclusive spatial } \\
\text { economy }\end{array}$ & $\begin{array}{l}\text { - Indicate the desired \& intended } \\
\text { pattern of land use } \\
\text { development in the province, } \\
\text { including the delineation of } \\
\text { areas in which development in } \\
\text { general or development of a } \\
\text { particular type would not be } \\
\text { appropriate } \\
\text { - Coordinate \& integrate the } \\
\text { spatial expression of the } \\
\text { sectoral plans of provincial } \\
\text { departments }\end{array}$ & $\begin{array}{l}\text { - Reflect the current state of } \\
\text { affairs in that area from a } \\
\text { spatial \& land use perspective } \\
\text { of the region } \\
\text { - Indicate desired patterns of } \\
\text { land use in that area }\end{array}$ & $\begin{array}{l}\text { Identify current \& future } \\
\text { significant structuring \& } \\
\text { restructuring elements of the } \\
\text { spatial form of the municipality, } \\
\text { including development corridors, } \\
\text { activity spines \& economic nodes } \\
\text { where public \& private } \\
\text { investment will be prioritised \& } \\
\text { facilitated }\end{array}$ & $\begin{array}{l}\text { - \% of poverty by regions } \\
\text { - \% of urban poverty } \\
\text { - \% of rural poverty } \\
\text { - Population density by distribution (i.e. } \\
\text { urban \& rural areas) } \\
\text { - Percentage of population who live in } \\
\text { the } 10 \% \text { most deprived areas } \\
\text { (wards/districts). }\end{array}$ \\
\hline $\begin{array}{l}\text { Facilitate the inclusion } \\
\text { of all persons \& areas }\end{array}$ & $\begin{array}{l}\text { - Give effect to relevant national } \\
\text { policies, priorities, plans \& } \\
\text { legislation; }\end{array}$ & $\begin{array}{l}\text { - Provide a spatial representation } \\
\text { of the land development } \\
\text { policies, \& objectives of the } \\
\text { province, which must include } \\
\text { the province's growth \& } \\
\text { development strategy where } \\
\text { applicable }\end{array}$ & $\begin{array}{l}\text { - Give effect to national \& } \\
\text { provincial policies, priorities, } \\
\text { plans \& planning legislation }\end{array}$ & $\begin{array}{l}\text { - Include a written \& spatial } \\
\text { representation of a five-year } \\
\text { spatial development plan for } \\
\text { the spatial form of the } \\
\text { municipality; } \\
\text { - Include a longer term spatial } \\
\text { development vision statement } \\
\text { for the municipal area which } \\
\text { indicates a desired spatial } \\
\text { growth \& development pattern } \\
\text { for the next } 10 \text { to } 20 \text { years }\end{array}$ & $\begin{array}{l}\text { - Wellbeing index } \\
\text { - \% population with access to internet } \\
\text { - \% of population with access to clean } \\
\text { water } \\
\text { - \% of population with access to refuse } \\
\text { removal services } \\
\text { - \% of population with access to } \\
\text { electricity }\end{array}$ \\
\hline $\begin{array}{l}\text { Facilitate access to } \\
\text { secure forms of tenure }\end{array}$ & $\begin{array}{l}\text { - Give effect to relevant national } \\
\text { policies, priorities, plans \& } \\
\text { legislation; coordinate \& } \\
\text { integrate provincial \& } \\
\text { municipal spatial development } \\
\text { frameworks }\end{array}$ & $\begin{array}{l}\text { - Incorporate any spatial aspects } \\
\text { of relevant national } \\
\text { development strategies \& } \\
\text { programmes as they apply in } \\
\text { the relevant province }\end{array}$ & & $\begin{array}{l}\text { - Identify the designated areas } \\
\text { where a national or provincial } \\
\text { inclusionary housing policy } \\
\text { may be applicable } \\
\text { - Identify the designation of } \\
\text { areas in the municipality where } \\
\text { incremental upgrading } \\
\text { approaches to development \& } \\
\text { regulation will be applicable }\end{array}$ & $\begin{array}{l}\text { - \% of population with access to secure } \\
\text { tenure in urban areas } \\
\text { - \% of population with access to secure } \\
\text { tenure rural areas } \\
\text { - \% of land accessed under land reform } \\
\text { - \% of land accessed under land } \\
\text { restitution } \\
\text { - \% of land accessed under market } \\
\text { forces } \\
\text { - \% of inclusionary housing projects } \\
\% \text { or \# of incremental upgrading } \\
\text { projects }\end{array}$ \\
\hline
\end{tabular}

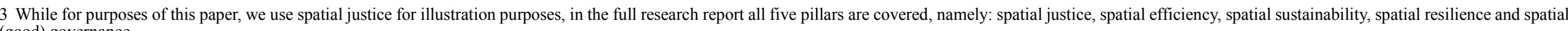
(good) governance. 


\begin{tabular}{|c|c|c|c|c|c|}
\hline \multirow{2}{*}{ SPATIAL JUSTICE } & \multicolumn{5}{|c|}{ CONTEXTUAL REALITIES (APPLICABLE TO SDFS) } \\
\hline & NATIONAL & PROVINCIAL & REGIONAL & MUNICIPAL & INDICATORS \\
\hline $\begin{array}{l}\text { Land use management } \\
\text { systems to facilitate all } \\
\text {-inclusiveness with } \\
\text { provisions that are fair, } \\
\text { just, flexible \& } \\
\text { appropriate } \\
\text { management of all } \\
\text { areas. }\end{array}$ & $\begin{array}{l}\text { - Indicate desired patterns of } \\
\text { land use in the Republic }\end{array}$ & $\begin{array}{l}\text { - Indicate the desired \& intended } \\
\text { pattern of land use } \\
\text { development in the province, } \\
\text { including the delineation of } \\
\text { areas in which development in } \\
\text { general or development of a } \\
\text { particular type would not be } \\
\text { appropriate }\end{array}$ & $\begin{array}{l}\text { - Provide basic guidelines for } \\
\text { spatial planning, land } \\
\text { development \& land use } \\
\text { management in that area }\end{array}$ & $\begin{array}{l}\text { Determine the purpose, desired } \\
\text { impact \& structure of the land } \\
\text { use management scheme to } \\
\text { apply in that municipal area }\end{array}$ & $\begin{array}{l}\text { - Updated LUMS } \\
\text { - Percentage of residents surveyed } \\
\text { finding the planning agency } \\
\text { transparent } \\
\text { - Percentage of residents surveyed } \\
\text { - Tinding the planning agency ethical } \\
\text { - Number in legal system } \\
\text { - \% budget emanating from cooperation } \\
\text { - \%reements } \\
\text { - Cofpublic debt } \\
\text { - ApLUMA Act } \\
\text { - Approved National SDF } \\
\text { - Approved Provincial SDF } \\
\text { - Approved Municipal SDF } \\
\text { - \% of vacancy rate } \\
\text { - \% of Senior posts not filled } \\
\text { - \% of professionals }\end{array}$ \\
\hline $\begin{array}{l}\text { Foster equitable access } \\
\text { to services \& resources }\end{array}$ & & $\begin{array}{l}\text { - Coordinate \& integrate the } \\
\text { spatial expression of the } \\
\text { sectoral plans of provincial } \\
\text { departments } \\
\text { - Provide a spatial representation } \\
\text { of the land development } \\
\text { policies, \& objectives of the } \\
\text { province, which must include } \\
\text { the province's growth \& } \\
\text { development strategy where } \\
\text { applicable }\end{array}$ & & $\begin{array}{l}\text { - Include estimates of the } \\
\text { demand for housing units } \\
\text { across different socioeconomic } \\
\text { categories } \\
\text { - Include estimates of economic } \\
\text { activity \& employment trends } \\
\text { \& locations in the municipal } \\
\text { area for the next five years } \\
\text { Determine the purpose, desired } \\
\text { impact \& structure of the land } \\
\text { use management scheme to } \\
\text { apply in that municipal area }\end{array}$ & $\begin{array}{l}\text { - \% of population having access to } \\
\text { services }>\% \text { of population not having } \\
\text { access to services } \\
\text {-\% of population having access to } \\
\text { resources }>\% \text { population not having } \\
\text { access to resources }\end{array}$ \\
\hline
\end{tabular}




\begin{tabular}{|c|c|c|c|c|c|}
\hline \multirow{2}{*}{ SPATIAL JUSTICE } & \multicolumn{5}{|c|}{ CONTEXTUAL REALITIES (APPLICABLE TO SDFS) } \\
\hline & NATIONAL & PROVINCIAL & REGIONAL & MUNICIPAL & INDICATORS \\
\hline $\begin{array}{lr}\text { Ensure } & \text { public } \\
\text { participation } & \& \\
\text { empowerment } & \\
\text { pertaining to policies, } \\
\text { legislation } \\
\text { procedures. }\end{array}$ & $\begin{array}{l}\text { The national government, a } \\
\text { provincial government \& a } \\
\text { municipality must participate } \\
\text { in the spatial planning \& land } \\
\text { use management processes } \\
\text { that impact on each other to } \\
\text { ensure that the plans \& } \\
\text { programmes are coordinated, } \\
\text { consistent \& in harmony with } \\
\text { each other }\end{array}$ & $\begin{array}{l}\text { - The national government, a } \\
\text { provincial government \& a } \\
\text { municipality must participate in } \\
\text { the spatial planning \& land use } \\
\text { management processes that } \\
\text { impact on each other to ensure } \\
\text { that the plans \& programmes } \\
\text { are coordinated, consistent \& in } \\
\text { harmony with each other }\end{array}$ & $\begin{array}{l}\text { - The national government, a } \\
\text { provincial government \& a } \\
\text { municipality must participate } \\
\text { in the spatial planning \& land } \\
\text { use management processes } \\
\text { that impact on each other to } \\
\text { ensure that the plans \& } \\
\text { programmes are coordinated, } \\
\text { consistent \& in harmony with } \\
\text { each other }\end{array}$ & $\begin{array}{l}\text { - Incorporate the outcomes of } \\
\text { substantial public engagement, } \\
\text { including direct participation in } \\
\text { the process through public } \\
\text { meetings, public exhibitions, } \\
\text { public debates \& discourses in } \\
\text { the media \& any other forum } \\
\text { or mechanisms that promote } \\
\text { such direct involvement. }\end{array}$ & $\begin{array}{l}\text { - The national government, a provincial } \\
\text { government \& a municipality must } \\
\text { participate in the spatial planning \& } \\
\text { land use management processes that } \\
\text { impact on each other to ensure that the } \\
\text { plans \& programs are coordinated, } \\
\text { consistent \& in harmony with each } \\
\text { other } \\
\text { - \# of Forums/Public Hearings held } \\
\text { - \# of Committees/Workshops held } \\
\text { - \# of Forums/Public Hearings held } \\
\text { - \# of Committees/Workshops held } \\
\text { - \% representation (gender, disability, } \\
\text { youth, aged \& women) } \\
\text { - \# of Forums/Public Hearings held } \\
\text { - \# of Committees/Workshops held } \\
\text { - \# of cross boundary municipal projects } \\
\text { - \% compliance } \\
\text { - Degree of credibility } \\
\text { - Approved Implementation \& Funding } \\
\text { Framework } \\
\text { - Approved Financial Implementation } \\
\text { Plan } \\
\text { - Approved Project Prioritisation Matrix } \\
\text { - Approved Capital Expenditure } \\
\text { Framework } \\
\text { - Approved Municipal SDF } \\
\text { - Approved spatial governance } \\
\text { - Approved Capital Expenditure } \\
\text { - Approvork project implementation Plan }\end{array}$ \\
\hline
\end{tabular}


Table 6. Spatial Planning Outcomes Indicator Framework

\begin{tabular}{|c|c|c|c|c|c|}
\hline Level & Spatial Sustainability & Spatial Efficiency & Spatial Justice & Spatial resilience & Spatial Governance \\
\hline International & $S M A R T$ growth & $\begin{array}{c}\text { Integrate land use \& transport planning } \\
\text { Implement Transit Orientated } \\
\text { Development (TOD) }\end{array}$ & $\begin{array}{l}\text { Entrench regional Integration } \\
\text { Gender, justice \& equity }\end{array}$ & $\begin{array}{c}\text { Engage in sustainable } \\
\text { development } \\
\text { Promote the green economy }\end{array}$ & Enhance multi-level governance \\
\hline \multirow{7}{*}{ National } & Protect unique land resources & $\begin{array}{l}\text { Optimize existing resources } \\
\quad \text { \&infrastructure }\end{array}$ & $\begin{array}{l}\text { Redress spatial imbalances } \\
\text { through access to land }\end{array}$ & $\begin{array}{l}\text { Flexibility of spatial plan \& } \\
\text { communities most likely to } \\
\text { suffer shocks }\end{array}$ & Ensure Legal backing \\
\hline & $\begin{array}{l}\text { Align land use measures with } \\
\text { environmental management }\end{array}$ & Minimise negative impacts \& risks & $\begin{array}{l}\text { Facilitate access to secure } \\
\text { tenure }\end{array}$ & Ability to adapt to changes & SPLUMA driven integrated spatial planning \\
\hline & Enhance equitable land markets & \multirow{5}{*}{ Streamline processes \& procedures } & $\begin{array}{c}\text { Foster equitable access to } \\
\text { services \& resources }\end{array}$ & $\begin{array}{l}\text { Ability to adapt \& support } \\
\text { sustainable livelihoods }\end{array}$ & $\begin{array}{c}\text { Intergovernmental \& collaboration [horizontal \& } \\
\text { vertical alignment] }\end{array}$ \\
\hline & $\begin{array}{l}\text { Consider life cycle costing - } \\
\text { infrastructure \& services }\end{array}$ & & \multirow{4}{*}{$\begin{array}{l}\text { Promote an inclusive spatial } \\
\text { economy }\end{array}$} & \multirow{4}{*}{$\begin{array}{l}\text { Incorporate disaster } \\
\text { mitigation \& risk } \\
\text { management }\end{array}$} & Foster Public Participation\& empowerment \\
\hline & Promote sustainable communities & & & & \multirow[b]{3}{*}{ Skills enhancement } \\
\hline & Balance urban \& rural development & & & & \\
\hline & $\begin{array}{c}\text { Promote financial mechanism \& } \\
\text { incentives that support spatial } \\
\text { resilience, adaptation, justice, } \\
\text { inclusive planning }\end{array}$ & & & & \\
\hline Provincial & $\begin{array}{l}\text { Present provincial spatial growth \& } \\
\text { development strategy }\end{array}$ & $\begin{array}{l}\text { Indicate desired \& intended land use } \\
\text { development patterns }\end{array}$ & $\begin{array}{c}\text { Spatial integration of } \\
\text { provincial sectoral plans }\end{array}$ & $\begin{array}{l}\text { Incorporate relevant national } \\
\text { development strategy \& } \\
\text { programme spatial aspects }\end{array}$ & $\begin{array}{l}\text { Provide a framework for coordinating Municipal } \\
\text { Spatial Development Frameworks }\end{array}$ \\
\hline \multirow[t]{2}{*}{ Regional } & \multirow[t]{2}{*}{ Indicate desired land use patterns } & $\begin{array}{l}\text { Provide basic guidelines for spatial } \\
\text { planning, land development \& land use } \\
\text { management }\end{array}$ & \multirow{2}{*}{$\begin{array}{l}\text { Give effect to the } \\
\text { development principles, } \\
\text { norms \& standards }\end{array}$} & \multirow[t]{2}{*}{$\begin{array}{l}\text { Consistency with } \\
\text { environmental legislation. }\end{array}$} & $\begin{array}{c}\text { Express national \& provincial policies, priorities, } \\
\text { plans \& planning legislation }\end{array}$ \\
\hline & & Reflect spatial \& land use status quo & & & Propose an implementation \& funding framework \\
\hline \multirow{5}{*}{ Municipal } & $\begin{array}{c}\text { Present } a \text { long term spatial } \\
\text { development vision statement for the } \\
\text { municipal area }\end{array}$ & $\begin{array}{l}\text { Package spatial form in written \& map } \\
\text { format }\end{array}$ & $\begin{array}{c}\text { Give effect to the } \\
\text { development principles, } \\
\text { norms \& standards set out in } \\
\text { chapter } 2\end{array}$ & \multirow{5}{*}{$\begin{array}{c}\text { Provide a strategic } \\
\text { assessment of the } \\
\text { environmental pressures \& } \\
\text { opportunities within the } \\
\text { municipal area }\end{array}$} & $\begin{array}{c}\text { Spatially express the co-ordination, alignment \& } \\
\text { integration of sectoral policies of all municipal } \\
\text { departments }\end{array}$ \\
\hline & $\begin{array}{l}\text { Quantify engineering infrastructure \& } \\
\text { services requirements for existing \& } \\
\text { future development }\end{array}$ & $\begin{array}{l}\text { Estimate demand for housing units \& the } \\
\text { planned location \& densities of future } \\
\text { housing developments }\end{array}$ & $\begin{array}{c}\text { Identify areas where a } \\
\text { national or provincial } \\
\text { inclusionary housing policy } \\
\text { may be applicable }\end{array}$ & & $\begin{array}{l}\text { Determine a spatial capital expenditure } \\
\text { framework for the development programmes }\end{array}$ \\
\hline & \multirow{3}{*}{ Estimate population growth } & $\begin{array}{c}\text { Estimate economic activity \& } \\
\text { employment trends \& locations in the } \\
\text { municipal area }\end{array}$ & \multirow{3}{*}{$\begin{array}{l}\text { Identify incremental } \\
\text { upgrading development areas }\end{array}$} & & \multirow{3}{*}{ Include an implementation plan } \\
\hline & & $\begin{array}{c}\text { Identify areas for detailed local plans; } \\
\text { shortened land use development } \\
\text { procedures applicable \& land use } \\
\text { schemes amended }\end{array}$ & & & \\
\hline & & $\begin{array}{l}\text { Determine the land use management } \\
\text { scheme to apply in municipal area }\end{array}$ & & & \\
\hline
\end{tabular}


Table 7. SPO Outcomes Measurement Matrix ${ }^{4}$

\begin{tabular}{|c|c|c|c|c|c|c|c|c|c|c|c|c|}
\hline \multirow{3}{*}{$\begin{array}{c}\text { Thematic } \\
\text { Area }\end{array}$} & \multirow{3}{*}{$\begin{array}{c}\text { Output } \\
\text { (as part of the SDF) }\end{array}$} & \multirow{3}{*}{$\begin{array}{l}\text { Key Issues Assessed } \\
\text { (Relate to the level of SDF) }\end{array}$} & \multirow{3}{*}{$\begin{array}{c}\text { Project } \\
\text { /Programe } \\
\text { or Activity } \\
\text { Identity or } \\
\text { Name }\end{array}$} & \multicolumn{8}{|c|}{ Assessment of Change / Efficiency Indicators } & \multirow{3}{*}{$\begin{array}{c}\text { Effectiveness } \\
\text { indicator } \\
4=\text { High, } 3= \\
\text { Substantial, } 2 \\
=\text { Modest, } 1= \\
\text { None }\end{array}$} \\
\hline & & & & \multicolumn{3}{|c|}{$\begin{array}{l}\text { Nature of change } \\
\text { (tick relevant box) }\end{array}$} & \multirow{2}{*}{$\begin{array}{c}\text { Indicator } \\
\text { of } \\
\text { change }^{5}\end{array}$} & \multicolumn{4}{|c|}{ Extent \& Reach of Change } & \\
\hline & & & & $\begin{array}{c}\text { Positive } \\
(+)\end{array}$ & $\begin{array}{c}\text { No } \\
\text { change } \\
(0)\end{array}$ & $\begin{array}{c}\text { Negative } \\
(-)\end{array}$ & & $\begin{array}{l}\text { Quantity / } \\
\text { Extent }\end{array}$ & $\begin{array}{l}\text { Population } \\
\text { affected } \\
(\#)\end{array}$ & $\begin{array}{c}\text { Urban/ } \\
\text { Rural }\end{array}$ & $\begin{array}{c}\text { Community } \\
\text { sector } \\
\text { targeted }\end{array}$ & \\
\hline \multirow{4}{*}{$\begin{array}{l}\text { Spatial } \\
\text { Justice }\end{array}$} & $\begin{array}{l}\text { Redress spatial \& other } \\
\text { imbalances through } \\
\text { access to \& use of land. }\end{array}$ & $\begin{array}{l}\text { Identify current \& future } \\
\text { significant structuring \& } \\
\text { restructuring elements of the } \\
\text { spatial form of the municipality, } \\
\text { including development corridors, } \\
\text { activity spines \& economic nodes } \\
\text { where public \& private investment } \\
\text { will be prioritised \& facilitated }\end{array}$ & & & & & & & & & & \\
\hline & $\begin{array}{c}\text { Facilitate the inclusion } \\
\text { of all persons \& areas }\end{array}$ & $\begin{array}{l}\text { Include a written \& spatial } \\
\text { representation of a five-year spatial } \\
\text { development plan for the spatial } \\
\text { form of the municipality } \\
\text { Include a longer term spatial } \\
\text { development vision statement for } \\
\text { the municipal area which indicates } \\
\text { a desired spatial growth \& } \\
\text { development pattern for the next } 10 \\
\text { to } 20 \text { years }\end{array}$ & & & & & & & & & & \\
\hline & $\begin{array}{c}\text { Facilitate access to } \\
\text { secure forms of tenure }\end{array}$ & $\begin{array}{l}\text { Identify the designated areas where } \\
\text { a national or provincial } \\
\text { inclusionary housing policy may } \\
\text { be applicable } \\
\text { Identify the designation of areas in } \\
\text { the municipality where } \\
\text { incremental upgrading approaches } \\
\text { to development \& regulation will } \\
\text { be applicable }\end{array}$ & & & & & & & & & & \\
\hline & $\begin{array}{l}\text { Land use management } \\
\text { systems to facilitate all } \\
\text {-inclusiveness with } \\
\text { provisions that are fair, } \\
\text { just \& flexible \& } \\
\text { appropriate for the } \\
\text { management of } \\
\text { disadvantaged areas }\end{array}$ & $\begin{array}{l}\text { Determine the purpose, desired } \\
\text { impact \& structure of the land use } \\
\text { management scheme to apply in } \\
\text { that municipal area }\end{array}$ & & & & & & & & & & \\
\hline
\end{tabular}

4 While the example is for spatial justice, in the research report all five pillars are covered, namely spatial justice, spatial efficiency, spatial resilience, spatial sustainability spatial (good) governance.

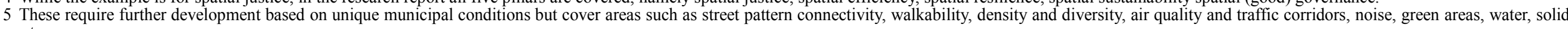
waste, energy. 


\begin{tabular}{|c|c|c|c|c|c|c|c|c|c|c|c|c|}
\hline \multirow{3}{*}{$\begin{array}{l}\text { Thematic } \\
\text { Area }\end{array}$} & \multirow{3}{*}{$\begin{array}{c}\text { Output } \\
\text { (as part of the SDF) }\end{array}$} & \multirow{3}{*}{$\begin{array}{l}\text { Key Issues Assessed } \\
\text { (Relate to the level of SDF) }\end{array}$} & \multirow{3}{*}{$\begin{array}{c}\text { Project } \\
\text { /Programe } \\
\text { or Activity } \\
\text { Identity or } \\
\text { Name }\end{array}$} & \multicolumn{8}{|c|}{ Assessment of Change / Efficiency Indicators } & \multirow{3}{*}{$\begin{array}{l}\text { Effectiveness } \\
\text { indicator } \\
4=\text { High, } 3= \\
\text { Substantial, } 2 \\
=\text { Modest, } 1= \\
\text { None }\end{array}$} \\
\hline & & & & \multicolumn{3}{|c|}{$\begin{array}{l}\text { Nature of change } \\
\text { (tick relevant box) }\end{array}$} & \multirow{2}{*}{$\begin{array}{c}\text { Indicator } \\
\text { of } \\
\text { change }\end{array}$} & \multicolumn{4}{|c|}{ Extent $\&$ Reach of Change } & \\
\hline & & & & $\begin{array}{c}\text { Positive } \\
(+)\end{array}$ & $\begin{array}{l}\text { No } \\
\text { change } \\
(0)\end{array}$ & $\underset{(-)}{\text { Negative }}$ & & $\begin{array}{l}\text { Quantity / } \\
\text { Extent }\end{array}$ & $\begin{array}{l}\text { Population } \\
\text { affected } \\
(\#)\end{array}$ & $\begin{array}{c}\text { Urban/ } \\
\text { Rural }\end{array}$ & $\begin{array}{l}\text { Community } \\
\text { sector } \\
\text { targeted }\end{array}$ & \\
\hline & $\begin{array}{l}\text { Foster equitable access } \\
\text { to services \& resources }\end{array}$ & $\begin{array}{l}\text { Include estimates of the demand } \\
\text { for housing units across different } \\
\text { socioeconomic categories } \\
\text { Include estimates of economic } \\
\text { activity \& employment trends \& } \\
\text { locations in the municipal area for } \\
\text { the next five years } \\
\text { Determine the purpose, desired } \\
\text { impact \& structure of the land use } \\
\text { management scheme to apply in } \\
\text { that municipal area }\end{array}$ & & & & & & & & & & \\
\hline & $\begin{array}{l}\text { Identify incremental } \\
\text { upgrading development } \\
\text { areas }\end{array}$ & $\begin{array}{l}\text { Include estimates of the demand } \\
\text { for housing units across different } \\
\text { socioeconomic categories } \\
\text { Include estimates of economic } \\
\text { activity \& employment trends \& } \\
\text { locations in the municipal area for } \\
\text { the next five years }\end{array}$ & & & & & & & & & & \\
\hline & $\begin{array}{c}\text { Ensure public } \\
\text { participation \& } \\
\text { empowerment } \\
\text { pertaining to policies, } \\
\text { legislation \& } \\
\text { procedures }\end{array}$ & $\begin{array}{l}\text { Incorporate the outcomes of } \\
\text { substantial public engagement, } \\
\text { including direct participation in the } \\
\text { process through public meetings, } \\
\text { public exhibitions, public debates } \\
\& \text { discourses in the media \& any } \\
\text { other forum or mechanisms that } \\
\text { promote such direct involvement. }\end{array}$ & & & & & & & & & & \\
\hline
\end{tabular}




\subsection{Spatial Planning Outcomes Delivery Institutional Architecture}

Whereas SPLUMA (2013) provides the necessary policy intent, an important part of the results delivery is a strong and empowered institutional mechanism to drive the policy. To successfully promote a strong vision and direction for spatial planning that is shared across the country and to ensure that the national principles of various frameworks have a clear mechanism for interpretation and contextualisation at the provincial and municipal planning level of planning, a national steering mechanism for spatial planning results delivery is required (GTRD, 2014c). Such a dedicated institutional mechanism could be in the form of a directorate or even an agency. The mechanism would, among other issues, address:

- Coordination in national spatial planning: Ensure there is clarity about what appropriately constitutes national spatial decisions through a centralized point where the spatial implications of national policies are articulated and passed down.

- Communication: Ensure that the national vision and principles and what they are seeking to achieve is communicated throughout the republic, including reaching the remotest municipality.

- Interpretation: Ensure uniform interpretation of the principles, their overall intention and spirit and the way in which policy-based planning works. The mechanism should also help in untangling the issues of legal and procedural complexities arising out of various legislation and legacies.

- Inter-governmental coordination: Ensure there is alignment of purpose about the roles of different spheres of government and their relationship with each other.

- Intra-governmental relations: At a national scale, most national government departments have policies which could be described as falling within the spatial planning arena. Unfortunately, these efforts have occurred largely in isolation of each other, with each sectoral emphasis understandably placing itself at centre-stage. This has profoundly negative developmental consequences as the sum of the parts is often not greater than the whole - but at best, is equal to or even much smaller than the whole.

- Capacity building and training: Lack of capacity is a stumbling block inhibiting fruitful spatial planning outcomes. Local and international research point to the centrality of capacity in determining the shape and impact of the spatial planning systems. This capacity deficit is exacerbated by the realization that many officials (practitioners) in the field of spatial planning and land use management are finding their original training inadequate to meet these demands.

- Data availability and management: A cardinal element of the SPO Measurement Framework is the ability to source, collect, store and manage reliable data for measurement purposes on a consistent basis. Initiatives such as the development of a National Spatial Information Framework are certainly pivotal as they will add value to and connect with existing data sourcing systems and institutions, for example, national initiative to coordinate development of spatial data infrastructure, including arrangements and standards for spatial and GIS data.

In order to build an agile and robust implementation vehicle with a resilient institutional memory for spatial planning in South Africa, it will be important to internalise the key success factors enumerated below. Figure 3, sketches key success factors relating to the steering mechanism for results delivery - responsible for the implementation of the measurement framework.

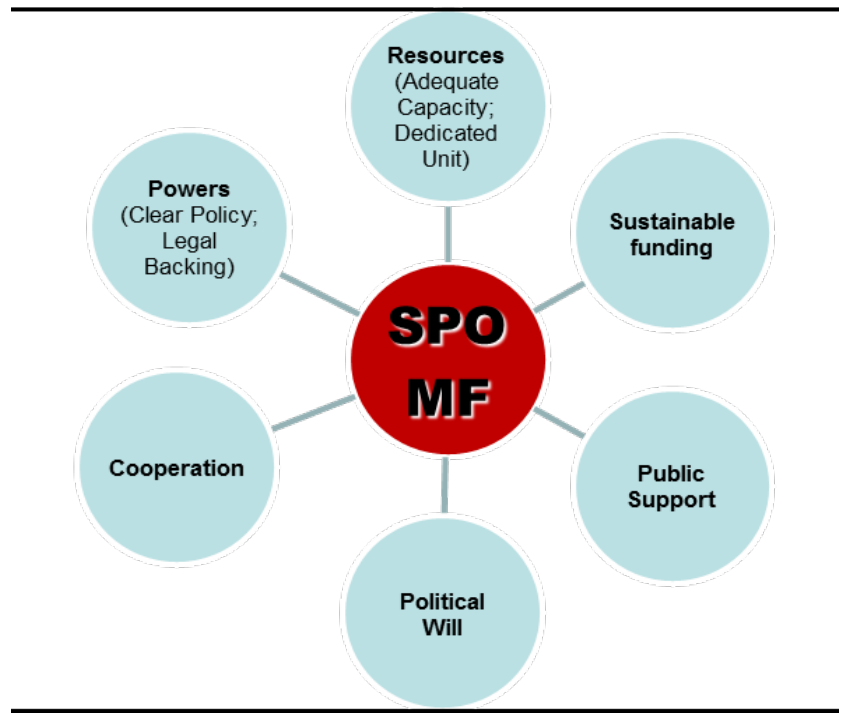

Figure 3. SPO measurement framework key success factors

- Strategic vision: An intervention of this magnitude needs to be anchored around a vision to transform the inherited space economy that reflects on and is underpinned by national imperatives of radically and inclusively transforming the economy, increasing employment and reducing poverty and inequality.

- Adequate resources (human and financial): Capacity for rapid implementation needs to be purposefully built at the outset (and subsequently) - including the wherewithal to enforce compliance. This needs to be driven relentlessly through the auspices of a dedicated institution with a clear and unequivocal mandate from the political leadership supported by adequate funding.

- $\quad$ Political will, cooperation, public support and effective communication: Because the delivery of spatial planning outcomes is heavily reliant upon the actions of a plurality of actors and agencies across different operationally independent socio-economic policy sectors, it requires a significant measure of cooperation - deliberately and proactively solicited - to ensure that spatial transformation begins to be entrenched and that this is corroborated through measurement. Clearly, 
politicians at all spheres of government who are fully committed to the spatial vision trajectory are pivotal in facilitating cooperation, communicating with and mobilizing public support.

- Governance and institutional architecture: Because spatial planning outcomes are complex organisms which are largely the function of decisions at different levels of the system by various role players pursuing mostly individual and often conflicting objectives, the need for a robust institutional framework around which individual and collective goals are mediated into a series of inter-related objectives to bring about local and regional economic development for the benefit of all cannot be over-emphasized. Integration and coordination between the actions of sectoral agencies/departments responsible for land use policy and management, transportation planning and infrastructure investment and maintenance; other spheres of government; and non-governmental role players, is imperative to ensure that actions are geared to and aligned towards the realization of the spatial vision. The institutional architecture needs to be permanent, inclusive, agile and oriented towards action - and tempered with significant political support, especially at the beginning.

- Powers: The implementation of effective spatial planning is predicated upon the development of relevant policies, laws, regulations, guidance procedures, organizational infrastructure and incentives within the ambit of a compelling vision. While SPLUMA provides the legislative anchor, other elements enumerated above are equally important to ensure measurable success.

- Stakeholder involvement: A cooperative, constructive attitude by all role players is a key to success: Given the magnitude of the intervention, all the parties involved must be firmly committed to realizing the spatial vision. Often, this cooperative spirit can remain dormant unless it is deliberately sought and packaged to achieve the spatial vision - and hence the need and importance of a dedicated institutional mechanism for implementing the SPO Measurement Framework.

\subsection{Integration with Other Measurement Systems}

The proposed SPO measurement framework can relatively easily be integrated into the Municipal balanced scorecard KPI and logic monitoring model system with ease [20]. Given that the logic model articulates short-term and long-term goals for performance and builds causal links between budgets, activities and expected results, the chain largely consists of inputs, processes, outputs, and outcomes. In the same vein, the SPO also builds and strengthens existing measurement systems such as performance benchmarking. Performance benchmarking involves municipalities comparing their current performance with historical performance, or against particular targets. They can also compare themselves with other municipalities or national and international standards for particular service areas. In addition, municipalities can conduct measurements which are essentially made up of:

- Internal spatial planning outcomes assessment: In this approach, the municipality examines its own spatial planning performance in corporate or self-assessment processes/reports

- External spatial planning outcomes assessment: External auditors assess performance through service inspections or compliance assessments.

- Spatial planning outcomes user assessment: This is linked to a customer perspective. It involves customer or citizen spatial planning outcomes satisfaction surveys.

- Spatial planning outcomes peer assessment: This examines professional standards of spatial planning outcomes by peers or colleagues, using standardised measurement tools, employee surveys or peer reviews.

\subsection{Challenges in Establishing Outcome-Based Spatial Planning}

Establishing outcomes-based spatial planning is fraught with challenges, including the following:

- Lack of knowledge: In the case of many smaller municipalities, particularly in the rural areas, little is known about then national vision and principles, what they are trying to achieve or why they are necessary.

- Interpretation: A great deal of difficulty is being experienced by officials and political decision-makers alike about the interpretation of the principles and the way in which policy-based planning works. A recurring theme in this regard is that many local authorities are trying to apply the principles on a one-by-one basis, without being informed by their overall intention and spirit. They then have to confront the situation that some principles potentially conflict with one another.

- Wilful recalcitrance: In some cases, officials are deliberately ignoring or undermining the principles and policies. There appear to be two main reasons for this. The first is ideological - they do not wish to confront change - and sometimes, reject the direction of that change. The second is a rejection of the idea of nationally-standardised principles or politically-approved policy plans. Coupled with a lack of shared vision about what planning should be trying to achieve, there is no clear, shared, understanding about how the planning system should be working in a reinforcing way to achieve desired results.

- Lack of inter-governmental coordination: There is evidence of considerable confusion about the roles of different spheres of government and their relationship with each other. The relationship between national and provincial planning is particularly unclear. The DFA is 
the one major piece of national planning legislation introduced since 1994, which provided some direction in terms of principles. However, in its entirety, it fails to provide a clear framework within which provinces can draw up local specific legislation but still, in principle, remain nationally unified.

- Lack of coordination in national spatial planning: This takes a number of forms. There is no clarity about what appropriately constitutes national spatial decisions (for example, there is evidence about issues having major impacts on world heritage sites being decided on entirely local, parochial perspectives). Operationally, there is no centralised point where the spatial implications of national policies are articulated and passed down. Frequently, national initiatives are almost entirely uninformed by provincial plans and may ride roughshod over them. There has been a major attempt at national level to change the dominant planning paradigm from a control-driven one to a more proactive developmental model. This is commendable. However, the significance and the implications of the shift have not been adequately communicated to other spheres of government and, in many places, the shift is being resisted.

- Relationship between provincial and local spheres of government: There is no clear conception of what the spatial elements of a provincial development plan should include. Many of the provincial growth and development plans are relatively weak in terms of spatial recommendations. Further, those spatial decisions that have been taken have frequently not been the result of consultation and collaboration with affected local authorities. Certain of the new provincial bills and acts, such as those emanating from KwaZulu-Natal and Gauteng, make specific requirements for coordination with local plans. In other provinces, this is not the case.

- Intra-governmental relations: At a national scale, most national government departments have policies which could be described as falling within the spatial playing field. Unfortunately, these efforts have occurred largely in isolation of each other, with each sectoral emphasis understandably placing itself at centre-stage. This has profoundly negative consequences. In provincial governments, it makes the task of producing a coherent policy framework extremely difficult. It encourages the tendency for sectoral issues to be considered in isolation, outside of any concern for the operation of the spatial unit as a totality, thereby making sound decision-making almost impossible.

- Issues of capacity: Lack of capacity is one of the most serious issues facing the planning system in South Africa. There are a number of dimensions to the problem. International research has shown that capacity is a key issue in determining the shape of the spatial planning system. While being acutely experienced in local and provincial governments, it is by no means confined to these spheres. There are also problems in national government. The more discretionary normative planning system ushered in by the DFA in 1995, and reinforced and extended by SPLUMA [11] requires a different kind of capacity to that required by the previous more rule-based system. Many officials in the field of spatial planning and development and management are finding their original training inadequate to meet these demands.

- Legal and procedural complexity: The current legislative situation is characterised by a high degree of legal complexity which, in turn, has generated considerable, and confusing, procedural complexities. Nationally, the coming into being of a new government in 1994 did not wipe the slate clean and lead in a new set of laws for the new democracy. The 1993 interim Constitution and the final 1996 Constitution both provided that all laws would continue to apply in the areas where they were applicable before these constitutions came into effect. Many of the national laws relating to planning are still in existence and the new national sectoral laws also deal with planning matters. Similarly, in local government, there is legal confusion. For example, a number of the major tools of management and control (such as zoning, the removal of title deed restrictions and building regulations) derive their powers from different legislation. Procedurally, many of the complexities created through national and provincial legislation are played out in this sphere.

\section{Conclusions}

A performance or result measurement framework is a mechanism that uses objective criteria (i.e. indicators) to monitor the logical structure of actions and inputs to ensure that they individually and collectively contribute to the desired outcomes and impacts. Necessarily, outcomes and impacts are enduring benefits to society that proposals are intended to achieve. In South Africa, the complex milieu of multi-level governance and diversity of sectoral priorities has implications in the determination and assessment of spatial planning outcomes. Typically, the horizontal axes of interactions among government departments are intersected by the vertical complexity of activities across different spheres of government. Thus the implementation of spatial objectives contained within planning policy is not only highly dependent upon the coordinating role of national government, but also local discretion over the interpretation of such policy guidance and the resources and action of developers and other stakeholders. In addition, the dynamic relationship between outputs and outcomes, mediated through different spatial levels, sectors and timeframes, add an extra layer of complexity. To reflect South Africa's now 
entrenched democratic values, current spatial planning paradigms place more emphasis on partnerships, consultations and consensus building. This means that effective plans that contribute to wider outcomes need to be assessed, in part at least, on their ability to be flexible and adaptable. Process efficiency is seen as being central to delivering the outcomes consistent with visions of sustainable communities and democratic norms.

The measurement framework for spatial planning outcomes together with the suite of indicators that describe the centrepiece of this article constitute a cardinal step in efforts aimed at building consensus on the desired spatial planning outcomes and the approach for measuring these outcomes. In this regard, it is of interest to observe that policy performance measurement is the norm for government operations in South Africa. Even high ranking politicians such as ministers sign performance agreements with the president. Thus, developing a measurement framework for spatial planning outcomes is in tandem with existing practice which often implies that acceptance by officials and practitioners may not necessarily be too onerous to procure. In order to facilitate untrammelled extensive use of the measurement framework, alignment should become the key catchword. Necessarily, the framework could be crafted into existing performance systems such as Strategic Plans and Annual Performance Plans, taking advantage of the notion that national departments working within a common cluster are expected to cooperate with each other in developing customized formats for their Strategic Plans and Annual Performance Plans that show the linkages between the different departments' mandates and their performance.

In addition, this Draft SPO Measurement Framework also needs to be aligned with other work aimed at addressing spatial transformation being undertaken, for example, by National Treasury relating to the development of Integration Zones, SACN's Performance Indicators, as well as the Integrated Urban Development Framework (finalised July 2014). This will have the effect of providing a single reporting platform for municipalities, thereby reducing duplication and facilitating service delivery (instead of municipalities getting bogged down with multiple reporting platforms which add little value to the process and ultimately hamper service delivery).

While the work described in this article is essentially work-in-progress as its practical value is tested overtime, allowing it to evolve into a robust instrument employed routinely across the board, it is important to emphasize the pivotal role of capacity building and training to arrive at the final framework and the accompanying indicators. Thus capacity building and training of prospective SPO Measurement Framework users (planners) and stakeholders (councillors) in respect of the spatial planning vision underwritten by SPLUMA, as well as regarding the collection, collation and analysis of data and generation of management reports to assist with untrammelled decision-making across all spheres of government needs to be proactively and carefully choreographed to harvest not only value for money, but also radically transformed great spaces, places and cultures.

A final conclusion is evident - there can be no doubt that transforming spatial planning processes into a results driven framework in South Africa is indeed a large and complex exercise requiring far reaching shifts involving institutional alignment and changes in established practice at all levels. Clearly, the need for an incremental approach couched within the ambit of a long term strategic vision that is designed to circumvent organizational overload and political failure cannot be over-emphasized. In this regard, sequencing will ensure that each set of reforms has cumulative effects for subsequent reforms and provide the basis for systematic change over time.

\section{Research Limitations}

In the main, the research limitation related largely to the stakeholder consultation and engagement process. By definition, the development of a spatial planning outcomes measurement framework is an iterative, consultative process depending for its robustness on the strength and intensity of the consultation and engagement process. Admittedly, while significant responses were garnered from the spatial planning fraternity, there was no discussion with other critical stakeholders such as the traditional leadership, community-based organisations, the business community, organised labour and politicians such as local councillors.

\section{Further Research}

Future research efforts could revolve around testing the spatial planning measurement framework in the field, that is, in a local authority. On the one hand, its affinity for data, including the cost of collecting, collation and analysis as well as the human resources required to undertake such a task, and on the other, its robustness in terms of accommodating and sensitively measuring spatial planning outcomes, could then be calibrated. One of the research outputs here could be a user-friendly guideline document that even the most resource deficient municipality could confidently employ. In addition, more research work needs to be done in terms of defining the spatial planning outcomes delivery institutional architecture with specific reference to the drivers of the system and the supporting funding and capacity building arrangements.

In addition, further research work is required in developing contextually relevant built environment measurement indicators in South Africa. This work would unpack the indices covering transportation, noise, air quality, green area, land use, water, solid waste, energy and lead to the development of South African built environment and 
municipal water sustainability index, cleaner treatment index, solid waste sustainability index, sustainability energy index, transportation sustainability index as well as composite sustainability indices. Further work would still be necessary regarding pilot testing and setting up demonstration projects regarding how such sustainability indices can be used in practice for the further advancement and development of the spatial built and non-built environments in South Africa.

\section{Acknowledgements}

The Authors wish to acknowledge Department of Rural Development and Land Reform (DRDLR) officials, Provincial, District and Local Municipal Officials, academics, consultants and practitioners who participated throughout the execution of the project work which has culminated in the production of this article.

\section{REFERENCES}

[1] UN-Habitat, Planning Sustainable Cities: Global Report on Human Settlements, Earthscan, London, 2009.

[2] UN-Habitat, State of the World's Cities, UN-Habitat, Nairobi, 2012.

[3] UN-Habitat, Urban Planning for City Leaders, UN-Habitat, Nairobi, 2013.

[4] Gwarajena TRD, Towards a framework for measuring spatial planning outcomes in South Africa: Final Draft Source Document. DRDLR, Pretoria, 2014a.

[5] Gwarajena TRD, Towards a framework for measuring spatial planning outcomes in South Africa: Stakeholder Engagement Report. DRDLR, Pretoria, 2014b.

[6] Gwarajena TRD, Towards a framework for measuring spatial planning outcomes in South Africa: Draft Final Report. DRDLR, Pretoria, 2014c.

[7] Department of Rural Development and Land Reform, White
Paper on Spatial Planning and Land Use Management, Pretoria, 2000.

[8] M. Oranje and M. Merrifield, National spatial development planning in South Africa 1930 - 2010: An introductory comparative analysis, Town and Regional Planning Journal, Bloemfontein, 2010.

[9] National Planning Commission, National Development Plan. Presidency, Pretoria, 2012.

[10] Economic Planning Department, New Growth Path, Pretoria, 2010.

[11] Department of Rural Development \& Land Reform, Spatial Planning \& Land Use Management Act, 2013 Act 16 of 2013, 2013.

[12] Presidency, Delivery Agreement: Annexure A. For Outcome 8 Delivery Agreements: Sustainable Human Settlements and Improved Quality of Household Life, Pretoria, 2010.

[13] RTPI, Measuring the Outcomes of Spatial Planning in England, Draft Report, Royal Town Planning Institute, RTPI, London, 2007.

[14] Spatium International Review, National indicators for evaluating the outcome of reinventing spatial planning in Serbia, Spatium International Review No 24 - March 2011 pp 27-36, 2011

[15] RTPI, Measuring the Outcomes of Spatial Planning in England, Final Report, Royal Town Planning Institute, RTPI, London, 2008.

[16] UN, Spatial Planning: Key Instrument for Development and Effective Governance with Special Reference to Countries in Transition. Geneva, Switzerland, 2008.

[17] L. Albrechts, Bridge the gap: From spatial planning to strategic projects. European Planning Studies, 14 (10), 1487-1500, 2006.

[18] WCED, Brundtland Commission Report, 1987

[19] South African National Assembly, Constitution of the Republic of South Africa (Act 108), Cape Town, 1996.

[20] R.S. Kaplan and D. P. Norton, 'Putting the balanced scorecard to work', Harvard Business Review, September - October, pp. 134-147, 1993. 